Trakya Eğitim Dergisi

Cilt 9, Sayı 3

Eylül 2019, 564-579

Geliş Tarihi: 26.12 .2018

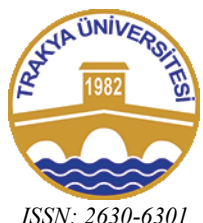

ISSN: 2630-6301
Trakya Journal of Education

Volume 9, Issue 3

September 2019, 564-579

\title{
Okulda Yönetici ve Öğretmenlerin Deneyimledikleri Duyguların Hiyerarşik Yapılarının İncelenmesi
}

\author{
Examining the Hierarchic Structures of Emotions Experienced by Teachers and \\ Administrators in the School
}

\section{Kamil YILDIRIM ${ }^{1}$}

\begin{abstract}
Öz: Bu çalışma okullarda öğretmenlerin ve okul yöneticilerinin yaşadıkları duyguların nasıl bir hiyerarşik yapı içerdiğini betimlemeye odaklanmıştır. Akdoğan (2016) tarafından geliştirilen 54 maddelik duygu durum ölçeği Aksaray ili şehir merkezindeki ilkokul, ortaokul ve lise kademesinden tabakalı örneklemeyle belirlenen katılımcılara 2017 Mart-Haziran döneminde uygulanmıştır. Betimleyici istatistikler, açımlayıcı faktör analizi ve korelasyon analiziyle toplam 633 katılımcıya ait veri incelenmiştir. Bulgular, alan yazında beliren çeşitli duygu sınıflamalarının yanı sıra Transfer kuramı, Sosyal Bilişsel Kuram ve Duygusal Olaylar Kuramları açısından değerlendirilmiştir. Okullarda en sıklıkla olumlu duygulardan sevgi, ilgi ve sabır; olumsuz duygulardan ise acıma, endişe ve hayal kırıklığ saptanmıştır. Olumlu duyguların olumsuz duygulara oranı katılımcılar için 1.31 olarak hesaplanmakla birlikte ideal oranın 1.50-2.00 aralığında olması beklenmektedir. Dördü olumlu 10 farklı hiyerarşik yapı tespit edilmiştir. En güçlü ilişki ağına sahip yap1 güven, gurur, coşku, cesaret, memnuniyet, hoşnut olma, inanma ve huzur duygularını içermiştir. Sonuçlar bağlamında okullarda duygusal körelme, kendine kapanma ve sinik davranışların düşük; bağlılık ve memnuniyetin yüksek olduğu belirlenmiş ve okullarda duygusal ortamın gelişimine hizmet edebilecek öneriler geliştirilmiştir.
\end{abstract}

Anahtar sözcükler: Duygu, okul, yönetici, öğretmen, hiyerarşik yapr

\begin{abstract}
This study focused on describing the hierarchical structure of the emotions experienced by teachers and administrators in schools. We implemented the 54-item Emotions Scale, which was developed by Akdoğan (2016), on the participants selected by stratified random technique in primary, lower secondary and secondary schools located in centre of Aksaray province in March-June, 2017. We analysed the data belonged to 633 participants through descriptive statistics, exploratory factor analysis and correlation analysis. The findings were evaluated in terms of Crossover Theory, Social-Cognitive Theory, Affective Events Theory beside various classifications of emotions. We revealed the most frequently experienced emotions as affection, attention and patience in positive group as well pity, worry and disappointment in negative group. The ratio of positive emotions to negative emotions was calculated as 1.31 for the participants, but the ideal ratio is expected to be in the range of 1.50-2.00. We identified ten emotional structures, four of which were positive. The structure, which has the strongest relationship network, includes trust, pride, enthusiasm, courage, satisfaction, pleased, belief and peace. Depending on the results, it is predicted that emotional blindness, self-closure and cynical behaviors in schools are at low level; commitment and satisfaction are at high level. We finally developed suggestions to serve the improvement of the emotional environment in schools.
\end{abstract}

Keywords: Emotion, school, administrator, teacher, hierarchic structure

\section{Introduction}

\section{EXTENDED SUMMARY}

In the context of organizational management and organizational behavior, employee's emotions attract an increasing concern. In examining the role of emotions and its relationship with administrative issues such as decision making, leadership, conflict etc. we first have to describe the sequence of emotions.

Beyond the interaction between cognitive and emotional health, both dimension affect people's social relations and they are also affected by the social environment. The Crossover Theory proposes the transfering of emotions among people; Social-Cognitive Theory suggests that people experience emotions while they observe others. Affective Events Theory says that our past experiences form our current emotional responses. In addition, emotions provide information about people's life conditions and how their environment is. Certain conditions and experiences lead to people have particular emotions. Jobs and tasks of a particular profession might cause employee's experience particular emotions more frequently. Not only face-to-face daily interaction, but also political demands and sanctions at the macro level leads to educators in school experience various emotions. As having critical position in forming children' improvement, teachers and administrators are expected to have good emotional characteristics. However, we have not comprehensive knowledge how often they experience which emotions. In line with this gap,

1 Dr. Öğr. Üys., Aksaray Üniversitesi, Eğitim Fakültesi, Eğitim Bilimleri Bölümü, e-posta: kamilyildirim@aksaray.edu.tr ORCID: 0000-0002-5212-3905 
we aimed to find out (i) participants' emotions; (ii) positive and negative emotions; (iii) self-directed and outer-directed emotions; (iv)cognitive, commitment, individual, imagination and others' imagination and (v) hierarchical structures of emotions.

\section{Method}

We used the survey method as a descriptive design in this study. The population consisted of totally 2806 including 2578 teachers and 228 administrators working in public schools at primary, lower secondary and secondary level in the city center of Aksaray province, Turkey We used the stratified random technique to draw the sample. We first listed 41 primary, 41 lower secondary and 38 secondary schools; then randomly selected .40 from each stratum and finally had 17 primary, 17 lower secondary and 15 secondary schools. We distributed instruments to all volunter participants in sampled schools, data belonged to totally 633 including 542 teachers, and 91 administrators were analysed. The proportion rate of represantation from population was .23. The participants were very experienced and 43 percent of them were women. Proportion of those who were in the first five years was $16 \%$. Primary schools with the rate of $41.5 \%$ had the highest proportion and $43 \%$ of participants was working in the crowded schools. $45.8 \%$ of the participants worked in schools having students from low SES.

We used the 54 item data-gathering instrument originally developed by Akdoğan (2016) for finding out the emotions of school administrators. Its validity was satisfied by the expert views and the internal reliability score was .92 (Cronbachs Alpha). It has five Likert scales (1: Never, 2: Rarely, 3: Sometimes, 4: Often, 5: Always). In the current study, we administered the instrument between March-June in 2017. This self-report instrument took nearly 30 minutes to fill.

Before analysing the data, we first checked the normality distribution through computing skewness and we had no score exceeded the limits of \pm 1 . Internal reliability score for the current study was computed as .93. We used descriptive statistics (frequency, percent, mean and standard deviation), exploratory factor analysis (EFA) and Pearson Correlation Coefficient (r) in analyses. In order to find out the hieararchic structure of emotions, we implemented EFA then we analysed the relationships among items in each factorial groups. We regarded the conditions that they are positively correlated at the .001 level (2-tailed). Other relationships were disregarded because of threatening the hieararchical structure.

\section{Result and Discussion}

Participants experienced the positive emotions more frequently $(\bar{X}=3.26)$ than negative emotions $(\bar{X}=2.48)$. Based on the rate of positive emotions to negative ones we put order some countries as headed by Croatian educators (1.69), then Swiss educators (1.68), and Turkish educators (1.31) and finally Chinese educators (1.07). All of these scores are far away from the score of five proposed by Sutton and Wheatley (2003) as an emotionally ideal teacher has. Depending on current and prior results, five seems to be invalid instead of it we suggest a range between 1.50-2.00.

We identified the most experienced emotions as affection, attention, patience, trust, empathy, pride and joy in this study. Relatively the most experienced negative emotions were pity, worry, dissappointment and anger. Jubilation were perceived as negative emotion because of cultural code. Among the ten hierarchical structures of emotions, the most powerful relations were belonged to trust, pride, enthusiasm, courage, satisfaction, pleased, belief and peace. Average power of relationship for this structure was $\mathrm{r}=.54$ and frequency level was 3.32 expressing that participants occasionally experience these emotions in this group. Second hierarchical structure $(\mathrm{r}=.52)$ included negative emotions of failure, despair, disappointment, worry, stress, grief and boredom. Frequency level of experiencing these emotions was rarely (2.64).

Based on the results, we ascert that schools have a positive emotional environment. Therefore, it leads to children to experience positive emotions, too. Moreover, depending on affective events theory, we anticipate that teaching and learning performance in school has a level that it does not cause teachers and administrators to feel worry and sadness. Another conclusion is that cultural characteristics affect the perception and expression of the emotion. Typical emotions characterizing the school personal are affection and joy. Because they appear as the most frequently experienced emotions in spite of the geographical, cultural and time differences. Based on the results, it is incorrect judgement to announce that teaching is a stressful job. We argue that there is a potential for improving institutional variables such as organizational learning, innovating and psychological security. As we consider the crossovering emotions among teachers and students, for administrative bodies we suggest the establishing a mechanism to help improving teachers' emotional management. Moreover, school administrations should consider and support teachers' educational initiatives to improve emotional environment in school. 


\section{GÍRIŞ}

Yönetim teorisi, örgütlerde, amaçları etkileyebilen çok çeşitli ögeleri tanımaya, anlamlandırmaya ve onlardan işlevsel biçimde yararlanmaya odaklanır. Yönetim süreçlerinin bütün aşamalarında üyelerin nitelikleri hem bireysel performansı hem de örgüt performansını şekillendirir (Bursalığlu, 2002; Lunenburg ve Ornstein, 2013; Robbins ve Judge, 2015). Örgütlerde, insan davranışlarını ve performansını şekillendiren boyutlardan biri duygulardır. Fayol'un birlik duygusu, Moreno'nun seçici yakınlık örneklerinde örgütlerin, duygulardan arındırılmış biçimde ele alınamayacağı kabul edilmektedir. İşin niteliği, işyükü, rekabet, çalışma şartları, yönetimsel uygulamalar, liderlik tarzı gibi etkenler çalışanların duygularını, davranışlarını ve performansını etkileyebilmektedir (Akdoğan, 2016; Li ve Ahlstrom, 2016; Oplatka ve Arar, 2018; Özdemir ve Koçak, 2018; Töremen ve Çankaya, 2008). Çalışanların güdülenmesi, liderlik, örgütsel değişim, gerginlik, çatışma ve kriz anlarındaki davranışlar ve örgütsel problemlerle baş etme gibi durumları yönetebilmek için çalışanlar duygu durumları bakımından tanınmalıdır (Akçay ve Çoruk, 2012; Çalık, 2003; Eren, 2001; Lunenburg ve Ornstein, 2013; Robbins ve Judge, 2015; Yamamoto, Gardiner ve Tanuto, 2014).

Duygular, kişinin iç ya da dış dünyasından kaynaklı çok çeşitli ihtiyaçlar temelinde tetiklenen hoşlanma veya acı hissetme şeklindeki tepkilerdir (Morgan, 2010; Scherer (2009). Duygu (emotion), kısa süreli fakat yüksek yoğunluklu yaşanan his (feeling) iken; duygu durumu (mood) uzun süreli ve başka nesne ya da kişiye yaygınlaştırılan istikrarlı duygusal tepkidir (Büyükgöze ve Özdemir, 2017; Robbins ve Judge, 2015; Weiss, 2002). Zihinsel süreçler ve duygular arasında karşılıklı bir etkileşim bulunmaktadır. Zihinsel boyut, duygular1; duygular da zihinsel performansı etkilemektedir (Murphy ve Hall, 2011). Zihinsel sağlık ve duygusal sağlığın birbiriyle etkileşim halinde olmasının ötesinde her iki boyut sağlıklı sosyal ilişkiler kurulmasını etkilediği gibi sosyal ortamdan da etkilenmektedir (Day ve Leitch, 2001). Duyguların temelinde algılama, hafızada tutma, muhakeme etme gibi zihinsel süreçler bulunmaktadır (Chernyshenko, Kankaraš, ve Drasgow, 2018). Fakat uyaranlara karş1 ilk olarak duygular harekete geçmekte ardından zihin devreye girmektedir. Farklı uyaranlar, bu uyaranların algılanması, tepkiler ve bu süreçte edinilen deneyimler duyguları şekillendirmektedir (Morgan, 2010; Weiss, 2002). Duyguların oluşumuna ilişkin Transfer Kuramı, duyguların kişiler arasında transfer edildiğini yani duygusal bakımdan kişiler arasında bir etkileşim olduğunu öne sürerken; Sosyal-bilişsel Yaklaşım bireylerin, etkileşimde bulundukları kişilerin davranışlarını gözlemleyerek duygular yaşadıklarını önermektedir. Duygusal Olaylar Kuramı ise geçmiş yaşantıların günümüzdeki duygusal tepkileri şekillendirdiğini öne sürmektedir. (Becker, Goetz, Morger ve Ranellucci, 2014; Büyükgöze ve Özdemir, 2017; Chernyshenko vd., 2018; Farouk, 2012; Pekrun, 2000; Weiss, 2002). Dolayısıyla, duygular kişinin yaşadığ 1 şartlar ve etkileşim ortamları hakkında bilgi içermektedir (Day ve Leitch, 2001; Farouk, 2012; Tarhan, 2006). Belirli koşullar ve yaşantılar, belirli duyguların yerleşmesine yol açabilir.

Duygular, farklı bakış açılarına göre farklı kategorilerde düzenlenebilmektedir. Robbins ve Judge, (2015) beş temel duygu olarak mutluluk, kizgınlık, korku, üzüntü ve iğrenme duygularının, diğer duyguların sinıflandırılmasına kaynaklık ettiğini belirtmektedir. Burić, Slišković ve Macuka (2018) coşku, övünç, sevgi, isteksizlik, klzgınlık ve ümitsizlik duygularını temel duygular olarak saptamışlardır. En yaygın sinıflandırma duyguları olumlu (mutluluk, neşe, iyimserlik vb.) ve olumsuz duygular (korku, nefret, iğrenme vb) şeklinde ayırmaktır (Akçay ve Çoruk, 2012; Akdoğan, 2016; Chen, 2016). Bir başka bakış açısıyla duygular içe yönelen ve dişa yönelen duygular şeklinde sınıflanabilir. Başkalarına yönelen imrenme, kıskanma gibi duygular dışa yönelen; kişinin kendine yönelen hayal kırıklığı gibi duygular ise içe yönelen duygular şeklinde belirtilmektedir (Akdoğan, 2016; Ayçiçek, 2012; Yaylacı, 2006). Bir başka sınıflandırmada duygular bilişsel, bağlılık, bireysel, imgesel ve diğer imgelem duyguları biçiminde sınıflandırılmıştır. Merak, ilgi, sıkıntı vb duygular bilişsel; nefret, sevgi gibi duygular bağlllık; keder, keyif, öfke gibi duygular bireysel; suçluluk, utanma gibi duygular imgesel ve küçümseme, saygı gibi duygular ise diğer imgelem duyguları olarak ayrılmaktadır (Bakioğlu, 2014). Parrott (2001) ise duyguları hiyerarşik şekilde üç dereceye ayırmıştır. Başat duygular sevgi, coşku, şaşırma, kızgınlık, üzüntü ve korku iken ikincil düzeyde her bir başat duyguya bağlı gelişen ikincil duygular sıralanmaktadır. Örneğin sevgi başat duygusunun ikincil duyguları bağlllık, neşe, özlem ve şehvet olarak sıralanmaktadır. Ardından ikincil düzeydeki duygularla ilişkili üçüncü düzey duygular sıralanmaktadır. Farklı bakış açılarına bağlı olarak önerilen bu sınıflandırmalar farklı doğurgulara yol açmaktadır.

Bir mesleğe özgü yapılan işlerin niteliği, çalışanların belirli duyguları daha sık ve yoğun yaşamalarına sebep olabilir. Okullar, insan ilişkilerinin ve duygularının yoğun yaşandığı ortamlardır (Barutçugil, 2002; Oplatka ve Arar, 2018; Yamamoto vd., 2014). Yalnızca günlük yüzyüze ilişkilerden kaynaklı duygular değil aynı zamanda makro düzeyde politik talepler ve buna bağlı uygulamalar sebebiyle de okul çalışanları çeşitli duygular yaşamaktadırlar (Saunders, 2013). Okulun temel işlevi olan eğitim 
öğretim faaliyetleri aynı zamanda çocukların ve gençlerin duygusal gelişimini sağlamaya yöneliktir. Okul bu işlevlerini başta öğretmenler olmak üzere okul çalışanları aracıllğıyla gerçekleştirir. Çocuklar ve gençlerle sürekli birlikte olmak, sevgi, sabır, coşku gibi belirli duyguları daha çok yaşamaya yol açmaktadır (Cangelosi, 2014). Okul yöneticileri ve öğretmenler birbirlerini duygusal bakımdan etkileyebildikleri gibi bunun sonucunda her iki taraf öğrencilerin duygularını etkilemektedir (Yamamoto vd., 2014). Etkileşen taraflar arasında duyguların transfer edildiği dikkate alındığında okul çalışanlarının duygu durumlarının önemi anlaşllabilir (Becker vd., 2014; Frenzel, Becker-Kurz, Pekrun, Goetz ve Lüdtke, 2017). Öğretmenlerin öğretim sürecinde sergilediği davranışlarla öğrencilerin yaşadığı hoşlanma ve kızgınlık duyguları ilişkilidir (Becker vd., 2014). Etkili bir öğretim için okul yöneticilerinin ve öğretmenlerin duygusal bakımdan sağlıklı olması ve duygularını yönetebilmesi kritik önemdedir (Chen, 2016; Day ve Leitch, 2001). Bu açıdan okul çalışanlarının duygusal dengeye sahip olması ve sorumluluk sahibi olması önemsenmektedir. Lunenburg ve Ornstein (2013)'e göre sorumluluk sahibi olanlar kendilerini çalışmaya daha iyi odaklamakta; duygusal bakımdan dengeli olanlar da sakin, soğukkanlı ve özgüvenli davranmaktadırlar. Çocukların ve gençlerin birçok yönden gelişimine doğrudan etki edebilme pozisyonunda olan öğretmenlerin ve okul yöneticilerinin mesleki yeterliklerinin yanı sıra duygu durumları bakımından da iyi olmaları beklenmektedir (Jennings \& Greenberg, 2009; Miller, 2012; Nias, 1996; Sezer, 2016; Şişman, 2014). Mesleğin gerektirdiği duygu durumu açısından okul çalışanlarının olumlu duygularının olumsuz duygularına oranının beş katı olması gerektiği ileri sürülmektedir. Bu oran, bir olduğunda yani olumlu duygular ile olumsuz duygular denkleştiğinde kişinin duygusal açıdan mesleğini sürdüremeyecek durumda olduğuna işaret etmektedir (Sutton ve Wheatley, 2003). Öğretmenler ve okul yöneticileri, yaşadıkları duygular nedeniyle fizyolojik ve psikolojik problemler yaşayabilmektedir (Bricheno, Brown ve Lubansky, 2009). Korku, endişe, nefret gibi olumsuz duygular egemen oldukça kişi olayları, durumları olumsuz algılama eğilimine girmektedir (Eren, 2001; Robbins ve Judge, 2015). Çok sayıda çalışma, olumsuz duygularını eylemlerine yansıtan okul çalışanlarının hem çocuk ve gençlerin gelişimini hem de okulun kurumsal yönünü negatif yönde etkilediğini göstermektedir (Demirtaş ve Küçük, 2016; Gasser, Grütter, Buholzer ve Wettstein, 2018; Kervanc1, 2008; Schenke, Ruzek, Lam, Karabenick ve Eccles, 2018; Töremen ve Çankaya, 2008). Başta öğretmenler olmak üzere; okul çalışanlarının en sıklıkla yaşadığı olumsuz duygular korku, utanma, suçluluk, incinme, küskünlük ve haksızlığa uğrama duygusu olarak belirtilmektedir (Day ve Leitch, 2001). İçinde bulunulan koşullar kişinin neşe, mutluluk, sevinç gibi olumlu duygular yaşamasına yol açabileceği gibi onu bunaltan, kaygılandıran, üzen olumsuz duygulara da sürükleyebilir (Leithwood ve Beatty, 2008). Örgüt yönetimi, çalışanlarına olumlu duyguları yaşayabilecekleri şartları oluşturmalıdır çünkü bu tür duyguların egemen olduğu yerlerde girişimciliğin, yaratıcılığın, örgütsel öğrenmenin ve psikolojik güvencenin daha yüksek olduğu bildirilmektedir (Edmondson, Kramer ve Cook, 2004; Sutton ve Wheatley, 2003; Yamamoto vd., 2014; Yildırım ve Yenipınar, 2017). Çalışanların duygu durumları liderlik, örgütsel değişim, örgütsel iklim, performans gibi yönetsel konuları etkilemektedir. Okullarda çocukların olumlu duyguları deneyimlemeleri yönetsel düzenlemelerle sağlanabilir. Çalışanların duygusal bakımdan tanınmadığı bir okulda yapılacak yönetsel düzenlemeler temelsiz olacaktır.

Literatür taramasında, öğretmenlerin ve okul yöneticilerinin yaşadıkları duyguları betimleyen çok az sayıda ulusal düzeyde çalışmaya erişilebilmiştir. Bu durum Akçay ve Çoruk (2012) tarafından da saptanmış ve bir yerdeki duygusal iklimi yönetebilmek için çalışanların duyguları bakımından betimlenmesinin önemi vurgulanmıştır. Öğretmenlerin duyguları, bu duygulara yol açan sebepler ve bu duyguların sonuçları üzerinde uluslararası düzeyde de çalışma sınırlılığı vurgulanmakla birlikte yakın yıllara doğru bir artış olduğu belirtilmektedir (Chen, 2016; Burić vd., 2018; Sutton ve Wheatley, 2003).

Türkiye'de yapılan çalışmalarda öğretmenlerin ve okul yöneticilerinin duygularını betimlemeye odaklı çalışma sınırlılığına karşın örgütsel güven, sinizm, bağlılık, tükenme, duygusal zekâ, duygusal iş yükü gibi belirli bir duygu ve bu duygunun başka değişkenlerle ilişkisini konu alan çok sayıda çalışmaya erişilmiştir. Örneğin Başaran (2011), Çokluk Bökeoğlu ve Y1lmaz (2008) ve Paker (2009) örgütsel güven üzerinde çalışmışlardır. Kahveci ve Demirtaş (2015), Kalağan ve Güzeller (2010) sinizm üzerinde çalışırken Babaoğlu, Altun ve Çakan (2010), Cemaloğlu ve Şahin (2007), Gök (2016) ve Köse (2016) ise iş doyumu, duygusal bağl1lık ve duygusal tükenme üzerinde çalışmışlardır. Özdemir ve Koçak (2018) öğretmenlerin duygusal iş yükü ve algıladıkları liderlik tarzı arasındaki ilişkiyi incelemişlerdir. Üstlenilen rol gereği sergilenen duygular ile gerçekte deneyimlenen duygular farklı olabilir. Görev, iş çeşitliliği, yetki bakımından çeşitli pozisyonlarda deneyimlenen duygular farklı olmakla birlikte Türkiye'de öğretmen ve okul yöneticilerinin duygularını betimleme açısından erişilebilen en ilgili çalışma Akdoğan (2016)'ın okul yöneticilerinin yaşadıkları duyguları betimlemeye odaklı karma desenli çalışmasıdır. Anılan çalışmanın nicel boyutunda okul yöneticilerinin en yoğun yaşadıkları duygular sevgi, ilgi, sabır, güven ve merhamet 
şeklinde saptanırken; nitel boyutunda ise en yoğun yaşanılan duygular mutluluk, üzüntü, endişe, çaresizlik ve sevinç şeklinde belirlenmiştir. Türkiye'deki çalışmalara göre uluslararası düzeyde öğretmenlerin duygularını betimlemeye yönelik daha fazla çalışmaya erişilmiştir. Kyriacou ve Sutcliffe (1978) İngiltere'de farklı kademelerden araştırdıkları öğretmenlerin beşte birinin yüksek düzeyde kaygı yaşadıklarını ve bu kaygının temel sebeplerinin öğrenci davranışları, çalışma şartları ve zaman baskısı olduğunu saptamışlardır. Day ve Leitch (2001) İngiltere ve Kuzey İrlanda'da yarı-zamanlı yükseklisans eğitimi yapmakta olan iki ayrı gruptaki öğretmenlerin otobiyografilerini inceleyerek mesleki gelişim, kişilik, duygular ve zihinsel deneyimlerinin ilişkisini saptamışlardır. Öne çıkan diğer alanların altında onları besleyen temel sebebin duygular olduğunu öne sürmüşlerdir. Sutton ve Wheatley (2003) öğretmenlerin en sıklıkla sevgi, coşku, memnuniyet, hoşlanma, gurur, heyecan, kızgınlık, suçluluk, utanç, kaygı, ümitsizlik ve üzüntü duygularını yaşadıklarını belirlemişlerdir. Skaalvik ve Skaalvik (2009) Norveçli öğretmenler üzerinde yaptıkları çalışmada duygusal bakımdan körelmenin öğretmenlerin başkalarıyla ilişkilerini olumsuz etkilediği sonucuna ulaşmışlardır. Bahia vd. (2013) Portekizli ilköğretim ve lise öğretmenleriyle yaptığı nitel çalışmada öğrencilerle etkileşimlerinde yaşadıkları olumlu duyguları coşku, isteklilik, keyif ve memnuniyet şeklinde saptamışlardır. Becker vd. (2014) İsviçre'nin Almanca konuşulan bölgesinde sekiz akademik odaklı okulda (gymnasium) dört farklı derste (Almanca, İngilizce, Fransızca ve Matematik) öğrencilerin görüşleri temelinde öğrencilerin kendilerinin ve öğretmenlerinin duygularını betimlemeye çalışmışlardır. Ders sırasında belirli aralıklarla kayıt yapan bir kaydedici aracılı̆̆ıyla öğrenciler üç duygu (kızgınlık, kaygl, mutluluk) durumunu betimlemişlerdir. Çalışma sonunda öğrenci ve öğretmenlerin duygu durumları arasında bir uyum olduğu; öğretmenlerin daha yüksek düzeyde mutluluk yaşarken daha az kızgınlık yaşadıkları bulunmuştur. Yamamoto vd. (2014) ABD'de dokuz okul yöneticisinin olumsuz kritik olaylarda yaşadıkları duyguları incelemiştir. Çalışma sonunda okul yöneticilerinin, kritik olaylar aracılığıyla kendilerini duygusal yönden geliştirdiklerini bulmuşlardır. Chen (2016) tarafından Hong Kong ve Çin'deki ilköğretim okulu öğretmenlerinin duygularını betimlemeyi amaçlayan çalışmada beş temel duygu olarak coşku, sevgi, üzüntü, kızgınlık ve korku saptanmıştır. Öğrencilerle ve meslektaşlarla olumlu ilişkiler, okul ve anne-babalar tarafından tanınma olumlu duygulara yol açarken; haksızlığa-adaletsizliğe uğrama, meslektaşlar arasında rekabet, işteki düzensizlikler ve politika ve toplum tarafından dayatılan baskılar olumsuz duygulara yol açmaktadır. Frenzel vd. (2017) tarafından gerçekleştirilen boylamsal çalışmada Almanya' da ilköğretim kademesindeki öğretmen ve öğrenciler arasındaki coşkunun (enjoyment) geçişi incelenmiştir. Bu kapsamda öğretmenlerin istekli/arzulu (enthusiastic) olma hali öğrenciler tarafından yüksek düzey olarak algılanırken; öğretmenler kendilerini orta düzeyde coşkulu olarak betimlemişlerdir. Öğrencilerin derse katılımı (engagement) ise öğretmenler tarafından daha düşük düzeyde algılanmıştır. Öğretim yılının başında yüksek olan değerlerin dönemin bitimine doğru azaldığı gözlemlenmiştir. Burić vd. (2018) tarafından gerçekleştirilen ve beş farklı katılımcı grubu üzerinde yürütülen karma desenli çalışmada Hırvatistan'daki ortaokul kademesindeki öğretmenlerin sınırlı sayıdaki duygusu (coşku, gurur, sevgi, isteksizlik, kızgınlık ve ümitsizlik) incelenmiştir. Söz konusu çalışmada öğretmenlerin olumlu duygularının ortalaması çok yüksek düzeyde; olumsuz duyguları ise düşük düzeyde bulunmuştur.

Literatürde, yönetim bilimi, daha özelde eğitim yönetimi ve öğretmen yetiştirme açısından, farklı kültürel bağlamlarda duyguların betimlenmesine odaklı bilimsel çalışma boşluğu bildirilmektedir (Akçay ve Çoruk, 2012; Chen, 2016; Robbins ve Judge, 2015; Sutton ve Wheatley, 2003). Kültürel bağlamın yanı sıra motivasyon, liderlik, örgütsel değişim gibi faktörler bakımından da çalışanların duygu durumlarının tanınması ihtiyacı belirmektedir. İletişim ve sosyal etkileşimin yoğun yaşandığı okullarda çalışanların duygusal yönden tanınması ve duygusal iklim, sosyal ortamın düzenlenmesi önemlidir. Yönetsel müdahale ve düzenlemeler için öncelikle ilgilenilen sorun betimlenmelidir. Duyguların transferi (crossover) teorisi, sosyal-bilişsel teori ve duygusal olaylar teorisi doğrultusunda öğretmenlerin duygularını betimlemek aynı zamanda öğrencilerin duyguları, öğretmenlerin çalışma şartları, öğretmenler arasındaki iletişim ve etkileşimin niteliği ve okulun yönetim tarzı hakkında da bilgi sağlayacaktır. Çünkü öğretmenlerin okulda ve sınıfta yaşadıkları duygular, deneyimlerinin bir sonucu olarak kabul edilmektedir (Becker vd., 2014; Büyükgöze ve Özdemir, 2017; Day ve Leitch, 2001; Farouk, 2012; Frenzel vd., 2017; Scherer, 2009; Tarhan, 2006; Weiss, 2002). Bu gerekçeler dikkate alınarak araştırmanın amaç ve alt amaçları belirlenmiş̧ir. Bu çalışmanın temel amacı okullarda öğretmenlerin ve yöneticilerin yaşadığı duyguları betimleyerek hiyerarşik yapılarını incelemektir. Alt amaçlar ise (i) duyguların yaşanma sıklığını; (ii) olumlu ve olumsuz duyguların yaşanma sıklığını; (iii) içe yönelen ve dışa yönelen duyguların yaşanma sıklığını; (iv) bilişsel, bağlılık, bireysel, imgesel ve diğer imgelem duyguların yaşanma sıklığını ve (v) yaşanan duyguların nasıl bir hiyerarşik yapıya sahip olduğunu ortaya koymaktır. 


\section{YÖNTEM}

$\mathrm{Bu}$ çalışma tarama modelinde betimsel desende gerçekleştirilmiştir.

\subsection{Evren örneklem}

Araştırmanın evrenini, 2016-2017 öğretim yılında Aksaray İli şehir merkezindeki ilkokul, ortaokul ve lise kademesindeki devlet okullarında görev yapan 2578 öğretmen ve 228 yönetici olmak üzere toplam 2806 kişi oluşturmuştur (https://aksaray.meb.gov.tr/www/strateji-gelistirme-hizmetleri/dosya/37). Örnekleme almada, çoklu örneklem alma yaklaşımıyla tabakalı ve tesadüfi örneklem alma yöntemleri kullanılmıştır (Büyüköztürk, Çakmak, Akgün, Karadeniz ve Demirel, 2014; Fraenkel, Wallen ve Hyun, 2012). Öncelikle kademelere göre okul listeleri oluşturulmuş ve toplam 41 ilkokul, 41 ortaokul ve 38 lise arasından 40 oranıyla 17 ilkokul, 17 ortaokul ve 15 lise seçilmiştir. Liselerdeki çeşitliliği örnekleme yansıtabilmek amacıyla dört Mesleki Teknik, üç İmam-Hatip ve sekiz genel lise kasıtlı olarak belirlenmiştir. Örnekleme giren okullardaki öğretmen ve yöneticilerden gönüllü olanların tamamına veri toplama aracı uygulanmış ve üzerinde analiz yapılan 542 öğretmen ve 91 yönetici olmak üzere toplam 633 katılımcının demografik bilgileri Tablo 1'de gösterilmiştir.

Tablo 1'e göre katılımcıların mesleki olarak oldukça kıdemli oldukları söylenebilir. Halen çalıştıkları okuldaki kıdemleri incelendiğinde katılımcıların yarısından fazlasının en az üç yıldır birbirlerini tanıdıkları söylenebilir. Okul türüne göre dağılımda en yüksek oran ilkokul kademesindedir. Kademe düzeyi yükseldikçe toplam içindeki temsiliyet oranları azalmaktadır. Meslek liseleri kategorisi mesleki teknik ve imam-hatip liselerini içermektedir. Katılımeılar 18 farklı branştan oluşmaktadır. Branşlar yeniden kodlanarak, sınıf, fen-matematik, dil-sosyal, sanat-meslek olmak üzere; dört kategoride betimlenmiştir. Bir başka ifadeyle branşlar sınıf, sayısal, sözel ve meslek olarak gruplanmıştır. Okul büyüklüğü öğretmen sayısına göre hesaplanmıștır. Katılımcıların yaklaşık yarısı büyük okullarda görev yapmaktadır. Okulun sosyo-ekonomik düzeyi katılımcıların algısına göre belirlenmiştir. Yöneticilerden okulun genelinde, öğretmenlerden ise sınıf öğretmeni oldukları öğrencilerin anne-babalarının gelir getiren bir işte çalışma ve eve giren gelir durumuna göre öğrencileri oranlamaları istenilmiştir. Buna göre katılımcıların yarısından fazlası orta sosyo-ekonomik düzeyden öğrencilerin; \% 45.8'i ise alt sosyo-ekonomik düzeyden öğrencilerin olduğu okullarda görev yaptıklarını belirtmektedirler.

Tablo 1. Katılımcıların demografik özellikleri

\begin{tabular}{llllllc}
\hline Katılımc1 Özellikleri & $f \%$ & 1 & 2 & 3 & 4 & Toplam \\
\hline Cinsiyeti & $f$ & 271 & 362 & - & - & 633 \\
1: Kadın 2: Erkek & $\%$ & 42.8 & 57.2 & - & - & 100 \\
Toplam kıdemi (yıl) & $f$ & 99 & 133 & 126 & 275 & 633 \\
1: 1-5 2: 6-10 3: 11-15 4: 16 & $\%$ & 15.6 & 21.0 & 19.9 & 43.4 & 100 \\
Halen görev yaptığı okuldaki kıdemi (yıl) & $f$ & 157 & 121 & 170 & 185 & 633 \\
1: Illk 2: 1-2 3: 3-5 4: $6^{+}$ & $\%$ & 24.8 & 19.1 & 26.9 & 29.2 & 100 \\
Okul türü & $f$ & 263 & 167 & 107 & 96 & 633 \\
1: Ilkokul 2: Ortaokul 3: Genel Lise 4: Meslek Lisesi & $\%$ & 41.5 & 26.4 & 16.9 & 15.2 & 100 \\
Branş & $f$ & 234 & 124 & 177 & 98 & 633 \\
1: Sinıf 2: Fen ve Matematik 3: Dil ve Sosyal 4: Sanat ve Meslek & $\%$ & 37.0 & 19.6 & 28.0 & 15.5 & 100 \\
Okul büyüklüğü (öğretmen sayıs1 temel alınmıştır) & $f$ & 136 & 227 & 270 & - & 633 \\
1: Küçük 2: Orta 3: Büyük & $\%$ & 21.5 & 35.9 & 42.7 & - & 100 \\
Okulun sosyo-ekonomik düzeyi & $f$ & 290 & 335 & 8 & - & 633 \\
1:Alt 2:Orta 3:Üst & $\%$ & 45.8 & 52.9 & 1.3 & - & 100 \\
\hline
\end{tabular}

\subsection{Veri toplama aracı}

Duyguların tanımlanması, tespit edilmesi ve nesnel biçimde ölçülmesindeki zorluk çalışma sayısındaki sınırlılığın temel sebepleri arasında gösterilmiştir (Zembylas, 2005). Bu zorluğun üstesinden gelebilmek için çeşitli veri toplama girişimleri yapılmaktadır. Gözlem yoluyla, vidyo kaydedip inceleyerek, laboratuvar ortamlarında görüntüleme cihazları kullanılarak ya da katılımcıların kişisel beyanlarıyla duygular belirlenmeye çalışılmaktadır (Burić vd., 2018; Harter ve Aroro, 2010; Oplatka ve Arar, 2018). Bu yöntemler arasında ekonomik olması ve uygulamasındaki kolaylık nedeniyle kişisel beyanlara dayalı veri toplama en çok tercih edilen yol olarak değerlendirilmiştir (Burić vd., 2018). Avantajlı yönlerinin yanı sıra kişisel beyana bağlı duyguların betimlenmesi katılımcıların hatırlamasını ve samimiyetini temel aldığından 
gerçeği yansıtmayacağı varsayımıyla eleştirilmektedir (Becker vd., 2014). Bu çalışmada belirli bir zaman diliminde (Mart-Haziran arasındaki dört aylık sürede) katılımcıların deneyimledikleri duygular onların kişisel beyanlarıyla saptanmaya çalışılmıştır. Duygular, anlık yaşanan hisler olduğundan kişisel beyana bağlı ölçümlerde istikrarlı duygusal tepkiler olarak nitelenen duygu durumunun belirlendiği ifade edilmektedir (Becker vd., 2014; Robbins ve Judge, 2015). Bu nedenle bu çalışmada katılımcıların duygu durumları betimlenmektedir.

Türkiye'de öğretmenlerin duygularını betimlemeye yönelik herhangi bir araştırmaya erişilememiş olması ve Türkiye dışındaki çalışmalarda ise belirli ve sınırlı sayıdaki duygulara odaklı çalışmaların olması (Burić vd., 2018; Chen, 2016; Frenzel vd., 2017), bu araştırma için duyguların çeşitliliği açısından daha kapsamlı bir ölçme aracı ihtiyacı hissettirmiştir. Scherer (2009), duygulara sebep olan durumların çeşitliliği temelinde duygu çeşitliliğinin dikkate alınmasını vurgular. Bu çerçevede, ihtiyaca cevap verebilecek en uygun ölçme aracı olarak Akdoğan (2016) tarafindan okul yöneticilerinin duygularını incelemek amacıyla geliştirilen ölçme aracı belirlenmiştir. Söz konusu ölçme aracında 54 farklı duygunun yaşanma sıklığı beşli likert (1:Hiç, 2:Nadiren, 3:Bazen, 4:Sıkça, 5:Sürekli.) ölçeğinde ve yaşanma şiddeti üçlü likert ölçeğinde (1:Düşük, 2:Orta, 3:Yüksek) saptanmaktadır. Anılan ölçme aracının kapsam geçerliği literatür taramasıyla ve uzman görüşü alınarak sağlanmıştır. İç tutarlık katsayısı ise $\alpha=.92$ olarak hesaplanan söz konusu çalışmada AFA gerçekleştirilmemiştir.

$\mathrm{Bu}$ çalışmada ise ölçüt geçerliği kontrol edilmiştir. Ölçüt geçerliği için özellikle Chen (2016) ve Burić vd. (2018) tarafından geliştirilen ölçme araçlarından yararlanılmıştır. Bu iki çalışmadan ilkinde Parrott (2001) tarafından önerilen hiyerarşik duygu sınıflaması temel alınmıştır. Toplam 55 duyguya açımlayıcı ve doğrulayıcı faktör analizi uygulanmasının ardından beş temel duyguyla aşamalı biçimde ilişkilendirilen toplam 26 duyguya sahip bir ölçek geliştirilmiştir. Burić vd. (2018), duyguları bir durumla eşleyerek bir ölçme aracı geliştirmiştir. Oysa öğretmenler, birden fazla duyguyu tek bir olaya bağlı olarak yaşayabilmektedir. Deneyimlenen duyguları betimlemeyi amaçladığı için mevcut çalışmada duyguların bir durumla eşleştirilmesinden kaçınılmıştır. Ayrıca Oplatka ve Arar (2018)'ın çalışmasında bahsedilen duygular da ölçüt geçerliği açısından yararlanılmıştır. Anılan çalışmalarda belirtilen duyguların Akdoğan (2016) tarafından geliştirilen ölçme aracında kapsandığı görülmüştür. Duyguların sınıflandırılmasında ise literatürden yararlanılmıştır (Akçay ve Çoruk, 2012; Akdoğan, 2016; Ayçiçek, 2012; Bakioğlu, 2014; Burić vd., 2018; Chen, 2016; Robbins ve Judge, 2015; Yaylac1, 2006). Veri toplama aracı basılı halde arkalı önlü tek bir yapraktan oluşan bir doküman şeklinde düzenlenmiş ve uygulanmıştır.

\subsection{Veri toplama süreci ve verilerin analizi}

Veri toplama aracı, gerekli izinlerin alınmasının ardından katılımcılardan gönüllü olanlara onların gerçek çalışma ortamlarında uygulanmıştır. 2017 yılı Mart-Haziran dönemindeki dört aylık sürede okullara gidilerek veriler toplanmıştır. Toplam 652 katılımcıya matbu veri toplama aracı dağıtılmış ve bunlardan 647'si geri alınmıştır. Eldeki formlar normlara uygunluk açısından incelenerek yarısından çoğu boş bırakılan, yalnızca aynı seçenek işaretlenen ya da belirli bir motif oluşturan toplam sekiz anket geçersiz sayılmıştır. Formlar kodlanarak veriler istatistik paket programı IBM SPSS 22 programına işlenmiştir. Analiz öncesinde veriler, kayıp değerler (missing), yinelemeler (duplication) ve uç değerler (outliers) açısından gözden geçirilmiştir. Kayıp değerler seri ortalamalarıyla değiştirilmiştir. Uç değer taramasında yanlış girilen değerler, örneğin 3 yerine 33, gibi düzeltilmiştir. Yineleme analizi yedi yineleme tespit etmiş bunlardan biri korunarak diğerleri veri setinden silinmiştir. Böylece toplam 633 katılımcıya ait veri incelenmiştir. Veri analizi üç aşamada gerçekleştirilmiştir. Öncelikle duygular betimleyici istatistiklere göre incelenmiştir. Böylece deneyimlenme sıklığına göre duyguları karşılaştırma olanağı elde edilmiştir. Sonrasında literatür temel alınarak duygular sınıflandırılmıştır (olumlu-olumsuz, içe yönelen-dışa yönelen...). Üçüncü aşamada ise duyguların hiyerarşik bir yap1 oluşturup oluşturmadığı test edilmiştir. Hiyerarşik yapı incelemesinde iki aşamalı bir yol izlenmiştir. Öncelikle olumlu duygular kendi arasında açımlayıcı faktör analizine tabi tutulmuştur. Her bir faktörü oluşturan duygular belirlendikten sonra ikinci aşamada faktörü oluşturan duygular arasındaki ilişkiye bakılarak duygular sıralanmıştır. Analizlerde tanımlayıcı istatistikler (frekans, yüzde, $\overline{\mathrm{X}}, \mathrm{Ss}$ ), açımlayıcı faktör analizi (AFA) ve Pearson Momentler Çarpımı Korelasyon Katsayısı (r) kullanılmıştır. AFA için temel bileşenler yöntemi ve oblique döndürme tekniği kullanılmış, özdeğeri 1 ve üstü faktörlerin elde edilmesi tercih edilmiştir. Faktör yapısını oluşturan duyguların kendi aralarındaki ilişkiler $r$ ile incelenmiştir. İlişkilerde .001 düzeyinde çift yönlü anlamlı pozitif ilişki olması koşulu aranmıştır. Anlamsız veya nefatif yönlü ilişkilere sahip duygular hiyerarşik yapıya uygun olmadığı kabul edilerek yapıya dâhil edilmemiştir. Araştırmada kullanılan analizler için verilerin normal dağılıp dağılmadığı tek değişkenli normallik dağılımlarında kullanılan çarpıklık katsayısı ile kontrol edilmiştir. Verilerin çarpıklık katsayılarının \pm 1 sınırını aşmadığı görüldüğünden verilerin normal 
dağıldığı kabul edilmiştir (Çokluk, Şekercioğlu ve Büyüköztürk, 2010; Kline, 2011). Sürekli verilerin yorumlanmasında 1.00-1.79 arası 1 (Neredeyse hiç), 1.80-2.59 arası 2 (Nadiren), 2.60-3.39 arası 3 (Bazen) ve 3.40-4.19 arası 4 (Sıkça) ve 4.20-5.00 arası 5 (Neredeyse sürekli) olarak dikkate alınmıştır.

\section{BULGULAR}

Bulgular, araştırmanın alt amaçları dikkate alınarak sunulmaktadır.

\subsection{Duyguların yaşanma sıklığı}

Tablo 2, betimsel istatistikler yardımıyla katılımcıların hangi duyguyu hangi sıklıkta yaşadığını göstermektedir. Tabloya göre toplam 54 duygudan katılımcıların sıkça yaşadığ duygular sevgi, ilgi, sabır, güven, empati, gurur ve neşe duygularıdır (3.40 $\leq \overline{\mathbf{X}} \leq 3.67)$. Nadiren yaşanan duygular ise tiksinme, nefret, kıskanma, utanma, korkma, bencillik ve suçluluk duygularıdır (1.94 $\leq \overline{\mathbf{X}} \leq 2.16)$. Öğretmen ve yöneticilerin görüşleri arasında farklılığın en yüksek olduğu (1.09 $\leq \mathrm{Ss} \leq 1.13)$ duygular üstünlük, bağlanma, minnet duyma, kiskanma ve utanmadır. Görüşler arasında benzerliğin en yüksek olduğu $(.81 \leq \mathrm{Ss} \leq .90)$ duygular ise sevinme, cesaret, şaşırma, hoşnut olma ve güven duymadır.

Tablo 2. Duyguların yaşanma durumuna ilişkin betimsel istatistikler

\begin{tabular}{|c|c|c|c|c|c|c|c|c|c|c|c|c|c|}
\hline \multirow{2}{*}{ Duygular } & \multirow{2}{*}{ Kod } & \multirow{2}{*}{$\bar{x}$} & \multirow{2}{*}{ Ss } & \multicolumn{2}{|c|}{ Neredeyse hiç } & \multicolumn{2}{|c|}{ Nadiren } & \multicolumn{2}{|c|}{ Bazen } & \multicolumn{2}{|c|}{ S1kça } & \multicolumn{2}{|c|}{ Neredeyse Sürekli } \\
\hline & & & & $f$ & $\%$ & $\mathrm{f}$ & $\%$ & $f$ & $\%$ & $\mathrm{f}$ & $\%$ & $f$ & $\%$ \\
\hline Acıma & $\mathrm{C} 1$ & 2.94 & .94 & 44 & 7.0 & 141 & 22.3 & 279 & 44.1 & 145 & 22.9 & 24 & 3.8 \\
\hline Aldatılma & $\mathrm{C} 2$ & 2.28 & .94 & 140 & 22.1 & 246 & 38.9 & 185 & 29.2 & 56 & 8.9 & 6 & 0.9 \\
\hline Alınma & $\mathrm{C} 3$ & 2.32 & .99 & 136 & 21.5 & 249 & 39.3 & 173 & 27.3 & 61 & 9.6 & 14 & 2.2 \\
\hline Alışma & $\mathrm{C} 4$ & 3.19 & 1.06 & 50 & 7.9 & 99 & 15.6 & 221 & 34.9 & 208 & 32.9 & 55 & 8.7 \\
\hline Bağlanma & $\mathrm{C} 5$ & 3.07 & 1.11 & 60 & 9.5 & 128 & 20.2 & 211 & 33.3 & 175 & 27.6 & 59 & 9.3 \\
\hline Güven duyma & C6 & 3.46 & .90 & 15 & 2.4 & 70 & 11.1 & 219 & 34.6 & 267 & 42.2 & 62 & 9.8 \\
\hline Gurur duyma & $\mathrm{C} 7$ & 3.40 & .94 & 17 & 2.7 & 79 & 12.5 & 244 & 38.5 & 220 & 34.8 & 73 & 11.5 \\
\hline Beklentiye girme & $\mathrm{C} 8$ & 3.17 & 1.06 & 45 & 7.1 & 116 & 18.3 & 220 & 34.8 & 191 & 30.2 & 61 & 9.6 \\
\hline Bencillik & $\mathrm{C} 9$ & 2.13 & 1.02 & 202 & 31.9 & 224 & 35.4 & 144 & 22.7 & 48 & 7.6 & 15 & 2.4 \\
\hline Can S1kıntıs1 & $\mathrm{C} 10$ & 2.72 & 1.00 & 82 & 13.0 & 164 & 25.9 & 256 & 40.4 & 110 & 17.4 & 21 & 3.3 \\
\hline Cesaretlenme & $\mathrm{C} 11$ & 3.33 & .87 & 14 & 2.2 & 82 & 13.0 & 266 & 42.0 & 225 & 35.5 & 46 & 7.3 \\
\hline Coşku duyma & $\mathrm{C} 12$ & 3.32 & .91 & 20 & 3.2 & 78 & 12.3 & 264 & 41.7 & 219 & 34.6 & 52 & 8.2 \\
\hline Çaresizlik & $\mathrm{C} 13$ & 2.41 & 1.07 & 139 & 22.0 & 220 & 34.8 & 171 & 27.0 & 81 & 12.8 & 22 & 3.5 \\
\hline Başarısızlık & $\mathrm{C} 14$ & 2.41 & 1.07 & 140 & 22.1 & 211 & 33.3 & 188 & 29.7 & 68 & 10.7 & 26 & 4.1 \\
\hline Empati duyma & $\mathrm{C} 15$ & 3.45 & .99 & 22 & 3.5 & 74 & 11.7 & 225 & 35.5 & 219 & 34.6 & 93 & 14.7 \\
\hline Endişelenme & $\mathrm{C} 16$ & 2.90 & 1.00 & 56 & 8.8 & 157 & 24.8 & 246 & 38.9 & 145 & 22.9 & 29 & 4.6 \\
\hline Hayal Kırıklığı & $\mathrm{C} 17$ & 2.82 & 1.01 & 56 & 8.8 & 190 & 30.0 & 236 & 37.3 & 117 & 18.5 & 34 & 5.4 \\
\hline Hayran kalma & $\mathrm{C} 18$ & 2.83 & 1.01 & 58 & 9.2 & 180 & 28.4 & 236 & 37.3 & 128 & 20.2 & 31 & 4.9 \\
\hline Hiddetlenme & C19 & 2.73 & .98 & 70 & 11.1 & 182 & 28.8 & 252 & 39.8 & 107 & 16.9 & 22 & 3.5 \\
\hline Hoşnut olma & $\mathrm{C} 20$ & 3.27 & .89 & 21 & 3.3 & 87 & 13.7 & 267 & 42.2 & 219 & 34.6 & 39 & 6.2 \\
\hline Huzur hissetme & $\mathrm{C} 21$ & 3.19 & .98 & 33 & 5.2 & 112 & 17.7 & 232 & 36.7 & 214 & 33.8 & 42 & 6.6 \\
\hline Hüzünlenme & $\mathrm{C} 22$ & 2.75 & .92 & 45 & 7.1 & 205 & 32.4 & 271 & 42.8 & 85 & 13.4 & 27 & 4.3 \\
\hline İlgilenme & $\mathrm{C} 23$ & 3.64 & .99 & 21 & 3.3 & 57 & 9.0 & 167 & 26.4 & 272 & 43.0 & 116 & 18.3 \\
\hline İmrenme & $\mathrm{C} 24$ & 2.76 & 1.07 & 90 & 14.2 & 155 & 24.5 & 236 & 37.3 & 122 & 19.3 & 30 & 4.7 \\
\hline İnanma & $\mathrm{C} 25$ & 3.33 & .99 & 29 & 4.6 & 92 & 14.5 & 218 & 34.4 & 231 & 36.5 & 63 & 10.0 \\
\hline İsteksizlik & $\mathrm{C} 26$ & 2.58 & 1.03 & 95 & 15.0 & 209 & 33.0 & 220 & 34.8 & 83 & 13.1 & 26 & 4.1 \\
\hline Kaygılanma & $\mathrm{C} 27$ & 2.78 & .99 & 65 & 10.3 & 175 & 27.6 & 256 & 40.4 & 110 & 17.4 & 27 & 4.3 \\
\hline Kederlenme & $\mathrm{C} 28$ & 2.47 & .98 & 99 & 15.6 & 242 & 38.2 & 205 & 32.4 & 69 & 10.9 & 18 & 2.8 \\
\hline Kiskanma & $\mathrm{C} 29$ & 2.01 & 1.09 & 276 & 43.6 & 160 & 25.3 & 130 & 20.5 & 51 & 8.1 & 16 & 2.5 \\
\hline K1zma & $\mathrm{C} 30$ & 2.80 & .97 & 55 & 8.7 & 180 & 28.4 & 259 & 40.9 & 114 & 18.0 & 25 & 3.9 \\
\hline Korkma & C31 & 2.13 & 1.02 & 206 & 32.5 & 216 & 34.1 & 147 & 23.2 & 51 & 8.1 & 13 & 2.1 \\
\hline Memnuniyet & $\mathrm{C} 32$ & 3.23 & .93 & 26 & 4.1 & 100 & 15.8 & 250 & 39.5 & 219 & 34.6 & 38 & 6.0 \\
\hline Meraklanma & $\mathrm{C} 33$ & 2.98 & .96 & 41 & 6.5 & 135 & 21.3 & 289 & 45.7 & 129 & 20.4 & 39 & 6.2 \\
\hline Merhamet & $\mathrm{C} 34$ & 3.39 & 1.04 & 31 & 4.9 & 93 & 14.7 & 193 & 30.5 & 233 & 36.8 & 83 & 13.1 \\
\hline Minnet duyma & $\mathrm{C} 35$ & 2.66 & 1.10 & 117 & 18.5 & 145 & 22.9 & 240 & 37.9 & 100 & 15.8 & 31 & 4.9 \\
\hline Mutsuz olma & C36 & 2.44 & 1.03 & 117 & 18.5 & 240 & 37.9 & 177 & 28.0 & 78 & 12.3 & 21 & 3.3 \\
\hline Nefret & C37 & 1.98 & 1.06 & 276 & 43.6 & 164 & 25.9 & 133 & 21.0 & 47 & 7.4 & 13 & 2.1 \\
\hline Neşelenme & $\mathrm{C} 38$ & 3.40 & .92 & 20 & 3.2 & 76 & 12.0 & 226 & 35.7 & 254 & 40.1 & 57 & 9.0 \\
\hline Öfkelenme & C39 & 2.72 & .99 & 68 & 10.7 & 196 & 31.0 & 243 & 38.4 & 99 & 15.6 & 27 & 4.3 \\
\hline Rahatlama & $\mathrm{C} 40$ & 3.19 & .92 & 23 & 3.6 & 105 & 16.6 & 275 & 43.4 & 187 & 29.5 & 43 & 6.8 \\
\hline Sabir duygusu & $\mathrm{C} 41$ & 3.63 & .99 & 16 & 2.5 & 63 & 10.0 & 186 & 29.4 & 243 & 38.4 & 125 & 19.7 \\
\hline
\end{tabular}




\begin{tabular}{llrrrrrrrrrrrr} 
Sevgi hissetme & $\mathrm{C} 42$ & 3.67 & 1.03 & 22 & 3.5 & 61 & 9.6 & 158 & 25.0 & 252 & 39.8 & 140 & 22.1 \\
Strese kapılma & $\mathrm{C} 43$ & 2.70 & 1.02 & 75 & 11.8 & 197 & 31.1 & 231 & 36.5 & 102 & 16.1 & 28 & 4.4 \\
Suçluluk duyma & $\mathrm{C} 44$ & 2.16 & 1.04 & 198 & 31.3 & 221 & 34.9 & 140 & 22.1 & 60 & 9.5 & 14 & 2.2 \\
Saş̧rma & $\mathrm{C} 45$ & 2.64 & .89 & 58 & 9.2 & 209 & 33.0 & 285 & 45.0 & 62 & 9.8 & 19 & 3.0 \\
Şüphelenme & $\mathrm{C} 46$ & 2.35 & .90 & 105 & 16.6 & 271 & 42.8 & 194 & 30.6 & 54 & 8.5 & 9 & 1.4 \\
Tiksinme & $\mathrm{C} 47$ & 1.94 & 1.06 & 294 & 46.4 & 155 & 24.5 & 124 & 19.6 & 50 & 7.9 & 10 & 1.6 \\
Umutlanma & $\mathrm{C} 48$ & 3.15 & 1.03 & 50 & 7.9 & 98 & 15.5 & 246 & 38.9 & 188 & 29.7 & 51 & 8.1 \\
Ümidini yitirme & $\mathrm{C} 49$ & 2.28 & 1.06 & 172 & 27.2 & 215 & 34.0 & 158 & 25.0 & 72 & 11.4 & 16 & 2.5 \\
Utanma & $\mathrm{C} 50$ & 2.07 & 1.09 & 254 & 40.1 & 168 & 26.5 & 140 & 22.1 & 57 & 9.0 & 14 & 2.2 \\
Üstünlük duygusu & $\mathrm{C} 51$ & 2.26 & 1.13 & 210 & 33.2 & 164 & 25.9 & 166 & 26.2 & 73 & 11.5 & 20 & 3.2 \\
Üzülme & $\mathrm{C} 52$ & 2.77 & .99 & 71 & 11.2 & 161 & 25.4 & 269 & 42.5 & 107 & 16.9 & 25 & 3.9 \\
Yalnılılk & $\mathrm{C} 53$ & 2.27 & 1.06 & 180 & 28.4 & 199 & 31.4 & 174 & 27.5 & 64 & 10.1 & 16 & 2.5 \\
Sevinme & $\mathrm{C} 54$ & 2.71 & .81 & 30 & 4.7 & 228 & 36.0 & 274 & 43.3 & 95 & 15.0 & 6 & 0.9 \\
\hline
\end{tabular}

\subsection{Olumlu ve olumsuz duyguların yaşanma sıklığı}

Tablo 2'de olumlu duygu türü altında 22 adet hoşa giden, istenilen duygu olarak nitelenen pozitif duygular (sevgi, ilgi, umut, memnuniyet vb.) yer almaktadır. Diğerleri ise hoşa gitmeyen, istenilmeyen (endişe, hayal kırlklı̆̆l, mutsuzluk, suçluluk vb.) duygulardır. Olumlu duygular arasında en düşük sıklıkta yaşananlar minnet duyma ve sevinmedir. Katılımcıların \% 40'1 minnet duygusu ve sevinme duygusunu hiç yaşamadıklarını ya da nadiren yaşadıklarını belirtmektedir. Olumsuz duygular arasında bazen yaşandığı $(2.80 \leq \overline{\mathrm{X}} \leq 2.94)$ belirlenen acıma, endişe, hayal kırıklığl ve kızma göreli olarak en yüksek sıklıkta yaşanan duygulardır. Okullarda öğretmen ve yöneticilerin olumlu duyguları, olumsuz duygulara göre daha sıklıkla yaşadığı görülmektedir.

Sutton ve Wheatley (2003) tarafından önerilen parmak hesabına göre duygusal bakımdan iyi durumda olan bir öğretmenin olumlu duygularının olumsuz duygularına oranı beş olmalıdır. Bu bakımdan katılımcıların olumlu duygularının ortalaması $3.26(\mathrm{Ss}=.57)$ iken olumsuz duygularının oranı $2.48(\mathrm{Ss}=.60)$ 'dir. Olumlu duyguların, olumsuz duygulara oranı 1.31 olarak hesaplanmaktadır.

\section{3. İçe yönelen ve dışa yönelen duyguların yaşanma sıklığı}

Tablo 3, farklı bakış açılarına göre oluşturulan duygu sınıflamalarına ait betimsel istatistikleri içermektedir. Duygulardan bazıları (can sıkıntısı, çaresizlik, huzur, umutlanma vb.) bireyin kendine yönelik yaşanmaktadır. $\mathrm{Bu}$ tür duygular içe yönelen duygular olarak nitelenmektedir. Bu çalışmada, 27 adet içe yönelik duygu bulunmaktaydı. Diğerleri ise başkalarına yönelen (bağlanma, beklenti, empati, imrenme, minnet vb.) duygulardır. Tablo 3'e göre katılımcıların içe yönelen duyguları $\overline{\mathrm{X}}=2.82(\mathrm{Ss}=.44)$ ortalamaya sahip iken; dışa yönelen duygularının ortalaması $\overline{\mathrm{X}}=2.78(\mathrm{Ss}=.47)$ dir. Okullarda öğretmen ve okul yöneticilerinin kendilerine ve başkalarına yönelen duyguları arasında bir denge olduğu görülmektedir. Her iki duygu türünün "biraz" düzeyinde yaşandığı belirtilebilir. İçe yönelen duygulardan en sıklıkla yaşanan duygular sabır, gurur, neşe, cesaret ve inanmadır. Dişa yönelen duygulardan en sıklıkla yaşanılanlar ise sevgi, ilgi, güven, empati ve merhamet duygularıdır.

\subsection{Bilişsel, bağlılık, bireysel, imgesel ve diğer imgelem duygularının yaşanma sıklığı}

Duygular, bilişsel (ilgi, sıkıntı, merak vb.), bağl1lık (sevgi, sempati, nefret vb.), bireysel (keyif, keder, öfke vb.), imgesel (utanç, suçluluk gibi kişinin kendi imajına yönelik) ve diğer imgelem (saygı, küçümseme gibi başkalarının bize karşı hissettiğini sandığımız) duygular şeklinde sınıflandırılmaktadır (Bakioğlu, 2014). Tablo 3, bu sınıflandırma bakımından duyguların yaşanma sıklıkları temelinde tanımlayıcı istatistikleri içermektedir.

Tablo 3'te katılımcıların bilişsel ( $\overline{\mathrm{X}}=2.80, \mathrm{Ss}=.94)$, bağl1lık $(\overline{\mathrm{X}}=2.82, \mathrm{Ss}=.94)$, bireysel $(\overline{\mathrm{X}}=2.82, \mathrm{Ss}=.99)$, imgesel $(\overline{\mathrm{X}}=2.83, \mathrm{Ss}=1.06)$ ve diğer imgelem $(\overline{\mathrm{X}}=2.61, \mathrm{Ss}=1.11)$ duyguları bazen yaşadıkları görülmektedir. Bilişsel duygular arasında en yüksek sıklıkta yaşanan duygular ilgi, alışma ve beklentidir (3.17 $\leq \overline{\mathbf{X}} \leq 3.64)$. Bağlılık duyguları arasında en sıklıkla yaşanan duygular sevgi, empati ve merhamettir (3.39 $\leq \overline{\mathrm{X}} \leq 3.67)$. Bireysel duygular arasında en sıklıkla yaşananlar ise neşe, coşku ve hoşnutluktur (3.32 $\leq \overline{\mathbf{X}} \leq 3.40)$. İmgelem duyguları arasında en sıklıkla yaşananlar 
sabır, gurur ve cesaret (3.33 $\leq \overline{\mathbf{X}} \leq 3.63)$ iken diğer imgelem duyguları güven, üstünlük ve bencilliktir $(2.13 \leq \overline{\mathrm{X}} \leq 3.46)$.

Tablo 3. Farklı sınıflandırmalar açısından duyguların yaşanma durumuna ilişkin betimsel istatistikler

\begin{tabular}{|c|c|c|c|c|c|c|c|c|c|c|c|c|}
\hline \multirow{2}{*}{ Duygular } & \multirow{2}{*}{$\bar{x}$} & \multirow{2}{*}{ Ss } & \multicolumn{2}{|c|}{ Neredeyse hiç } & \multicolumn{2}{|c|}{ Nadiren } & \multicolumn{2}{|c|}{ Bazen } & \multicolumn{2}{|c|}{ Sikça } & \multicolumn{2}{|c|}{ Neredeyse Sürekli } \\
\hline & & & $\mathrm{f}$ & $\%$ & $\mathrm{f}$ & $\%$ & $\mathrm{f}$ & $\%$ & $\mathrm{f}$ & $\%$ & $\mathrm{f}$ & $\%$ \\
\hline Olumlu Duygular & 3.26 & .57 & 7 & 1.1 & 62 & 9.8 & 311 & 49.1 & 226 & 35.7 & 27 & 4.3 \\
\hline Olumsuz Duygular & 2.48 & .60 & 76 & 12.0 & 303 & 47.9 & 211 & 33.3 & 40 & 6.3 & 3 & 0.5 \\
\hline İçe Yönelen Duygular & 2.82 & .44 & 10 & 1.6 & 159 & 25.1 & 412 & 65.1 & 48 & 7.6 & 4 & 0.6 \\
\hline Dışa Yönelen Duygular & 2.78 & .47 & 8 & 1.3 & 224 & 35.4 & 346 & 54.7 & 51 & 8.1 & 4 & 0.6 \\
\hline Bilişsel Duygular & 2.80 & .94 & 18 & 2.8 & 200 & 31.6 & 337 & 53.2 & 72 & 11.4 & 6 & 0.9 \\
\hline Bağlılık Duyguları & 2.82 & .94 & 14 & 2.2 & 187 & 29.5 & 359 & 56.7 & 67 & 10.6 & 6 & 0.9 \\
\hline Bireysel Duygular & 2.82 & .99 & 9 & 1.4 & 170 & 26.9 & 401 & 63.3 & 47 & 7.4 & 6 & 0.9 \\
\hline İmgelem Duyguları & 2.83 & 1.06 & 9 & 1.4 & 183 & 28.9 & 366 & 57.8 & 68 & 10.7 & 7 & 1.1 \\
\hline Diğer İmgelem Duyguları & 2.61 & 1.11 & 64 & 10.1 & 239 & 37.8 & 264 & 41.7 & 55 & 8.7 & 11 & 1.7 \\
\hline
\end{tabular}

\subsection{Duyguların hiyerarşik yapısı}

Olumlu ve olumsuz duygulara AFA uygulanmıştır. Olumlu duygular için uygulanan AFA ile toplam 22 madde dört faktör altında toplanmıştır. Faktörler birlikte toplam varyansın .54'ünü açıklamaktaydı $(\mathrm{KMO}=.92, \mathrm{p}=.000)$. Olumsuz duygular için tekrarlanan AFA ile toplam varyansın .59 'unu açıklayan altı faktör altında 32 maddelik bir yapı üretilmiştir $(\mathrm{KMO}=.95, \mathrm{p}=.000)$. Her bir faktörü oluşturan maddelerin kendi aralarındaki ilişkiler incelenmiş; ilişkinin anlamlılığı, yönü ve gücü dikkate alınarak maddeler arasında hiyerarşi oluşturulmuştur. Tablo 4, faktörleri oluşturan (Fp: Pozitif duyguları içeren; Fn: Negatif duyguları içeren) maddeler arasındaki hiyerarşik yapıları göstermektedir.

Tablo 4. Duyguların hiyerarşik yapısı

\begin{tabular}{|c|c|c|c|c|c|c|c|c|c|c|}
\hline \multirow{2}{*}{$\begin{array}{c}\text { Tür } \\
\text { Faktör }\end{array}$} & \multicolumn{4}{|c|}{ Olumlu duygular } & \multicolumn{6}{|c|}{ Olumsuz duygular } \\
\hline & Fp1 & Fp2 & Fp3 & Fp4 & Fn5 & Fn6 & Fn7 & Fn8 & Fn9 & Fn10 \\
\hline $\mathrm{m} 1$ & Güven & İlgi & Alıșma & Minnet & Başarısızlık & Tiksinme & Şüphelenme & Aldat1lma & Meraklanma & Strese kapılma \\
\hline $\mathrm{m} 2$ & Gurur & Sevgi & Bağlanma & Merhamet & Çaresizlik & Nefret & Şaşırma & Alınma & İmrenme & Mutsuzluk \\
\hline $\mathrm{m} 3$ & Coşku & Neşe & Beklenti & Rahatlama & Hayal kırıklı & Kiskanma & Üzülme & Bencillik & Hüzünlenme & K1zma \\
\hline $\mathrm{m} 4$ & Cesaret & Umut & & & Endişelenme & Utanma & & & & Öfkelenme \\
\hline m5 & Memnuniyet & Empati & & & Kaygilanma & Suçluluk & & & & Hiddetlenme \\
\hline $\mathrm{m} 6$ & Hoșnut olma & Sabır & & & Kederlenme & Yalnızlık & & & & \\
\hline m7 & İnanma & & & & Can sıkıntıs1 & Ümitsizlik & & & & \\
\hline $\mathrm{m} 8$ & Huzur duyma & & & & & Korkma & & & & \\
\hline m9 & & & & & & Üstünlük & & & & \\
\hline
\end{tabular}

Tablo 4'te yer alan faktörler altındaki maddelerin aralarındaki ilişkiler (r) $\mathrm{p}=.001$ düzeyinde çift yönlü, pozitif ve $.25 \leq \mathrm{r} \leq .65$ aralığında ilişkiler sergilemiştir. Anlamlı ilişkiye sahip olmayan acıma duygusu hiyerarşik yapıya alınmamıştır. İlişkilerin gücü bakımından diğerleriyle karşılaştırıldığında en güçlü ilişkiye sahip maddeler sıralanmıştır. Buna göre $\mathrm{F}_{1}$ : Güven $\left(.66^{* *}\right)$ Gurur $\left(.52^{* *}\right) \operatorname{Coşku}\left(.65^{* *}\right)$ Cesaret $\left(.46^{* *}\right)$ Memnuniyet $\left(.51^{* *}\right)$ Hoşnut olma $\left(.50^{* *}\right)$ Inanma $\left(.47^{* *}\right)$ Huzur şeklinde sıralanmıştır. $F_{2}$ : Illgi $\left(.47^{* *}\right) \operatorname{Sevgi}\left(.48^{* *}\right) \operatorname{Neşe~}\left(.36^{* *}\right) \operatorname{Umut}\left(.29^{* *}\right) \operatorname{Empati}\left(.25^{* *}\right)$ Sabır biçiminde sıralanırken $\mathrm{F}_{3}$ : Alışma $\left(.45^{* *}\right)$ Bağlanma $\left(.39^{* *}\right)$ Beklenti olarak sıralanmıştır. Olumlu duyguların son faktörü ise $\mathrm{F}_{4}$ : Minnet $\left(.32^{* *}\right)$ Merhamet $\left(.30^{* *}\right)$ Rahatlama biçiminde sıralanmıştır. Olumsuz duygular arasındaki hiyerarşik sıra şu şekilde saptanmıştır. F5: Başarısızlık $\left(.61^{* *}\right)$ Çaresizlik $\left(.47^{* *}\right)$ Hayal Kırıklı̆̆ $\left(.55^{* *}\right)$ Endişelenme $\left(.53^{* *}\right)$ Kaygllanma $\left(.60^{* *}\right)$ Kederlenme $\left(.37^{* *}\right)$ Can Sikıntısı şeklinde siralanmıştır. F6: Tiksinme $\left(.65^{* *}\right)$ Nefret $\left(.61^{* *}\right)$ Kiskanma $\left(.56^{* *}\right)$ Utanma $\left(.57^{* *}\right)$ Suçluluk $\left(.54^{* *}\right)$ Yalnızlık $\left(.49^{* *}\right)$ Ümitsizlik $\left(.36^{* *}\right)$ Korkma $\left(.34^{* *}\right)$ Üstünlük biçiminde sıralanmıştır. $\mathrm{F}_{7}$ : Şüphelenme $\left(.53^{* *}\right)$ Şaşırma $\left(.39^{* *}\right)$ Üzülme şeklinde sıralanırken; $\mathrm{F}_{8}$ : Aldatılma $\left(.53^{* *}\right)$ Alınma $\left(.42^{* *}\right)$ Bencillik biçiminde dizilmiştir. F9: Meraklanma 


\section{$\left(.53^{* *}\right)$ Imrenme $\left(.39^{* *}\right)$ Hüzünlenme biçiminde sıralanmıştır. Son olarak $\mathrm{F}_{10}$ : Strese kapılma $\left(.53^{* *}\right)$ Mutsuzluk $\left(.39^{* *}\right)$ Klzma $\left(.53^{* *}\right)$ Öfkelenme $\left(.39^{* *}\right)$ Hiddetlenme biçiminde sıralanmıştır.}

\section{TARTIŞMA ve SONUÇ}

Örgüt yönetimi ve örgütsel davranış bağlamında giderek artmakta olan ilginin odaklandığı konulardan biri çalışanların duygularıdır. Karar verme, liderlik, çatışma gibi yönetimsel konularda duyguların oynadığı rol ve başka değişkenlerle ilişkisi incelenirken bazı temel sorunlarla karşılaşılmaktadır. Bunların başında duygunun tanımlanması, duygunun ölçülmesi ve duyguların betimlenmesi gelmektedir. $\mathrm{Bu}$ çalışma, okullarda öğretmen ve yöneticilerin duygularını betimlemeye odaklanmıştır.

$\mathrm{Bu}$ çalışmada, öğretmen ve yöneticilerin olumlu duyguları $(\overline{\mathrm{X}}=3.26)$, olumsuz duygulara $(\overline{\mathrm{X}}=2.48)$ göre daha sıklıkla yaşadıkları saptanmıştır. Önceki çalışmalarla karşılaştırıldığında sonuçlar arasında bir uyum olduğu görülmektedir (Akdoğan, 2016; Bahia vd., 2013; Becker vd., 2014; Burić vd., 2018; Chen, 2016). Örneğin İsviçre' de lise öğrencilerinin görüşlerine dayalı olarak yapılan çalışmada, öğretmenler orta düzeyde mutluluk yaşarken; düşük düzeyde kızgınlık ve kaygı yaşamaktadırlar (Becker vd., 2014). Hırvatistan'daki ortaokul kademesindeki öğretmenlerin olumlu duygularının ortalaması çok yüksek düzeyde; olumsuz duyguları ise düşük düzeyde bulunmuştur (Burić vd., 2018). Hong Kong ve Çin'li ilköğretim öğretmenlerinin olumsuz duyguları göreli olarak daha yüksek olmakla birlikte onlar için de olumlu duyguların yaşanma sıklığı daha yüksektir (Chen, 2016). Olumlu duyguların olumsuz duygulara oranına göre farklı ülkelerdeki eğitimciler karşılaştırıldığında Hırvat eğitimciler (1.69), İsviçreli eğitimciler (1.68), Türk eğitimciler (1.31) ve Çinli eğitimciler (1.07) şeklinde sıralanmaktadır. Bu oranlar, Sutton ve Wheatley (2003) tarafından önerilen duygusal bakımdan çok iyi durumdaki bir öğretmenin sahip olması gereken oranın (5.00) oldukça uzağındadır. Bu çerçevede Sutton ve Wheatley (2003) tarafindan önerilen bu oranın gerçekçi görünmediği sonucuna ulaşılmaktadır. Daha gerçekçi bir oran vermek gerekirse 1.502.00 aralığı önerilir.

Bu çalışmada öğretmen ve okul yöneticilerinin en sıklıkla sevgi, ilgi, sabır, güven, empati, gurur ve neşe duygularını yaşadıkları saptanmıştır. Bu duygular, önceki çalışmalarda da öne çıkan duygulardır (Akdoğan, 2016; Bahia vd., 2013); Burić vd., 2018; Chen, 2016; Sutton ve Wheatley, 2003). Eğitimcilerin bu tür duyguları daha sıklıkla yaşamaları eğitim ortamlarında olumlu duygusal ortamın varlığına işaret etmektedir. Daha düşük sıkl1kta yaşanmakla birlikte öğretmen ve okul yöneticileri, olumsuz duygular arasında göreli olarak en yüksek sıklıkta acıma, endişe, hayal kırıklı̆̆ ve kızma duygularını yaşamaktadırlar. Fakat Day ve Leitch (2001) okullardaki eğitimcilerin olumsuz duygular arasında en sıklıkla korku, utanma, suçluluk, incinme, küskünlük ve haksızlığa uğramışlık duygularını yaşadıklarını saptamışlardır. Bu tür farklılıklar, okulların bulunduğu çevrenin özellikleri ve eğitim sisteminin özellikleri ya da kültürel bağlamın etkisinden kaynaklanabilir (Eren, 2001; Lunenburg ve Ornstein, 2013; Robbins ve Judge, 2015). Örneğin Sevinme duygusu teorikte pozitif bir duygu olarak nitelenmesine karşın bu çalışmada negatif bir duygu olarak belirmiştir. Katılımcılar, sevinmeyi sevinç gösterisi şeklinde algılamış olabilir. Kültürel açıdan sevinç gösterisi olumsuz karşılandığından söz konusu duygu negatif grupta yer almıştır. Benzer bir durum Chen (2016) tarafından yapılan çalışmada Çinli öğretmenlerin sevgi duygusunu olumsuz duygu gibi algılamasında saptanmaktadır. Kültürel bağlam farklılığına karşın okullardaki eğitimcileri karakterize edebilecek duygular sevgi ve coşku duygularıdır. Çünkü bu duygular coğrafya, zaman ve kültür farklılıklarına karşın okuldaki eğitimciler tarafindan en yüksek sıklıkta yaşanan duygular olarak belirmektedir (Akdoğan, 2016; Bahia vd., 2013; Becker vd., 2014; Burić vd., 2018; Cangelosi, 2014; Chen, 2016; Sutton ve Wheatley, 2003). Okullardaki eğitimcilerin yaşadığı olumsuz duygular arasında literatürde en yoğunlukla ele alınan duygu endişe (kaygı, stres) ve tükenmişlik (ümitsizlik, çaresizlik) duygularıdır (Andrew, Richards, Hemphill, ve Templin, 2018; Babaoğlu vd., 2010; Bricheno vd., 2009; Cemaloğlu ve Şahin, 2007). Bu çalışmada endişe duygusunun orta düzeyde tükenme duygusunun ise çok düşük düzeyde yaşandığı saptanmıştır. Önceki çalışmalarda bu duyguların çok düşük düzeyde yaşandığı belirlenmiştir (Becker vd., 2014; Burić vd., 2018). Sonuçlar dikkate alındığında öğretmenlik mesleğini stresli bir meslek olarak nitelemek (Andrews vd., 2018) hatalı olacaktır. İncelenen duygulardan bir başkası korkudur. Bu çalışmada korku duygusunun nadiren yaşandığı belirlenirken Çinli öğretmenlerin sıklıkla yaşadığı saptanmıştır (Chen, 2016). Erişilebilen araştırma sınırlılı̆̆ sebebiyle bu konuda daha fazla karşılaştırma yapılamamaktadır.

Araştırmada duyguları çok düşük ya da çok yüksek düzeyde yani uçlarda yaşayanların sayısının çok az olması, katılımcıların genelinin dengeli bir duygusal duruma sahip olduklarına işaret etmektedir. Bu sonuç iki farklı tahmine yol açmaktadır. İlki katılımcıların rutinleşmiş, alışılmış bir eğitim-öğretim hayatı içinde oldukları; bir başka söyleyişle onlarda heyecan uyandırabilecek olayların oldukça sınırlı olduğu 
tahminidir. Diğeri ise, Lunenburg ve Ornstein (2013) tarafından tanımlanan eğitimcilerin duygusal karakterine ilişkindir. Onlara göre duygusal bakımdan dengeli olanlar sakin, soğukkanlı ve özgüvenli davranma eğilimindedir. Eren (2001) ve Robbins ve Judge (2015)'in belirlemelerine dayalı olarak mevcut çalışmaya katılan eğitimcilerin, karşılaştıkları olay ve durumları pozitif algılama eğiliminde oldukları tahmin edilmektedir. Bu tahmin aynı zamanda katılımcıların bulunduğu okullarda çocukların ve gençlerin duygusal gelişiminin ve okulun kurumsal yönünün olumlu olduğu çıkarımına yol açmaktadır (Demirtaş ve Küçük, 2016; Gasser vd., 2018; Kervancı, 2008; Schenke vd., 2018; Töremen ve Çankaya, 2008). Ayrıca, mevcut çalışmada katılımcıların bulunduğu okullarda örgütsel öğrenme, girişimcilik ve psikolojik güvence gibi kurumsal değişkenlerin geliştirilmesi için uygun bir potansiyelin varlığından da söz edilebilir (Edmondson vd., 2004; Yamamoto vd., 2014; Y1ldırım ve Yenipınar, 2017).

Çalışanlarda öfke, küçümseme, aşağılama gibi duygular yaygınsa bu durum örgütsel sinizmin belirtisi olarak kabul edilirken; okul çalışanlarının olumlu duygularının yüksek düzeyde olması ise örgütsel bağl1lık ve iş doyumu algılarının da yüksekliğinin belirtisi olarak görülmektedir (Demirtaş ve Küçük, 2016). Kaygı düzeyinin yüksek olması ise tükenmişlik belirtisi olarak kullanılmaktadır (Konan, Çetin ve Bozanoğlu, 2016). Mevcut çalışmada, öğretmen ve okul yöneticileri, bağlılık duygularını göreli olarak yüksek sıklıkta yaşarken bu tür duygular arasında en sıklıkla sevgi, empati ve merhamet duygularını yaşamaktadırlar. Illgi, alışma ve beklenti gibi bilişsel duygular ise bağlılık duygularından sonra en sıklıkla yaşanan duygu türleridir. Bu sonuç, öğretmenlerin duygusal körelme, kendine kapanma, sinik davranışlar sergilemekten uzak olduğuna işaret etmektedir (Andrews vd., 2018). Özellikle empatinin yüksek sıklıkta yaşanıyor olması, katılımcı öğretmen ve okul yöneticilerinin duygusal körelme eğiliminde olmadığını düşündürmektedir. Skaalvik ve Skaalvik (2009) duygusal körelmenin kişiler arası etkileşimi olumsuz etkilediğini saptamışlardır. Dolayısıyla mevcut çalışmada katılımcılar arasındaki etkileşimin canlı olduğu çıkarımı yapılabilir.

Duyguların hiyerarşik yapısı açısından en güçlü ilişki ağına sahip duygu grubu güven, gurur, coşku, cesaret, memnuniyet, hoşnut olma, inanma ve huzur duygu grubudur. Bu grup için ilişkinin ortalama gücü $\mathrm{r}=.54$ olup yaşanma sıklığı ortalaması ise beş üzerinden 3.32 'dir. Bu sonuç, öğretmen ve yöneticilerin okullarda olumlu bir duygusal iklime sahip olduklarını işaret etmektedir. İlişki gücü açısından ikinci sırada $(\mathrm{r}=.52)$ başarısızlık, çaresizlik, hayal kırıklığl, endişelenme, kaygılanma, kederlenme ve can sıkıntısının oluşturduğu hiyerarşik yapı gelmektedir. Olumsuz duyguların oluşturduğu bu gruptaki duyguların yaşanma sıklığı ortalaması ise 2.64'tür. Bu çalışmada ortaya çıkan yapılar Parrott (2001) tarafindan önerilen yapılardan farklı olsa da duyguların hiyerarşik yapısına ilişkin önerilen görüşü desteklemektedir. Hiyerarşik yapı oluşturan duyguların birbirini besleyen duygular olduğu ve okuldaki eğitimcilerin deneyimlerinin sonucunda ortaya çıktığı temel alındığında bazı çıkarımlara ulaşılabilir. Güven duygusunun beklentilerin karşılanmasıyla ortaya çıktı̆̆ı; gurur duygusunun başarının yaşanmasıyla ve buna bağlı coşku duygusunun ortaya çıktığ 1 düşünülebilir. Bunların ise yeni girişimler için cesareti ve elde edilen olumlu sonuçların memnuniyeti ve hoşnutluğu ortaya çıkaracağı ileri sürülebilir. Olumsuz duyguların oluşturduğu en güçlü yapıya bakıldığında temeli başarısızlığın oluşturduğu görülmektedir. $\mathrm{Bu}$ sonuçlardan hareketle eğitimcilerin girişimlerinin okul yönetimlerince desteklenerek bu girişimlerin başarıya ulaşması için çaba göstermeleri önerilir.

Araştırmada ulaşılan sonuçlar duyguların transferi (crossover) teorisi ve sosyal-bilişsel teori açısından da incelenebilir. Yamamoto vd. (2014) tarafından saptandığı üzere; okullarda öğretmen ve okul yöneticilerinin olumlu duygulara sahip olmaları, olumlu duygusal ortamı desteklediği gibi öğrencilerin de olumlu duygular yaşamalarına yol açması beklenmektedir. Çünkü, duyguların transfer edildiği belirlenmiştir (Becker vd., 2014; Frenzel vd., 2017). Bundan dolayı araştırmaya katılan okullarda öğretmen ve öğrenciler arasında en sıklıkla sevgi, ilgi, güven, empati duygularının yaşandığı tahmin edilmektedir. Öğretmenlerin, duygu durumları öğretimsel davranışlarına yansıyarak dolaylı olarak öğrencilerin duygu durumunu etkileyebildiğinden özellikle ders başlangıcında sınıfta olumlu bir duygusal iklim oluşturmaları önerilmektedir (Becker vd., 2014). Bu durum ise öğretmenlerin duygu yönetimi becerilerine bağlıdır.

Duygusal olaylar teorisine göre yaşanılan duygular geçmiş yaşantıların bir sonucudur (Büyükgöze ve Özdemir, 2017). Leithwood ve Beatty (2008)'e göre çalışanların yaşadıkları duygular, içinde bulundukları koşulların bir sonucudur. Öğretmen ve okul yöneticilerinin yaşadıkları duygular bir bağımlı değişken gibi dikkate alındığında onların bu duyguları yaşamalarına yol açan durumlar hakkında da bilgi sağlar. Okullarda yüzyüze ilişki ve etkileşimin en yoğun yaşandığı gruplar öğretmenler ve öğrencilerdir. Okullarda eğitimcilerin yaşadığı olumsuz duyguların kaynağında öğrencilerin olumsuz davranışları, olumsuz çalışma şartları, zaman baskısı (Kyriacou ve Sutcliffe, 1978), aşırı iş yükü, rol yetersizliği ve belirsizliği (Andrews vd., 2018) sıralanmaktadır. Mevcut çalışmanın sonucunda erişilen olumlu duyguların daha sıklıkla yaşanıyor olması öğretmen ve öğrenciler arasında daha ağırlıkla olumlu ilişki ve etkileşimin 
varlığına işaret etmektedir. Cangelosi (2014)'ye göre çocuklarla birlikte olmak sevgi, sabır ve coşku gibi duyguları yaşamaya yol açmaktadır. Eğer öğrenciler öğretime katılır ve ilerleme sağlarlarsa bu durum öğretmenlere coşku ve isteklilik duyguları hissettirmekte fakat öğrencilerin sorumluluk üstlenmemesi ve öğrenme gerçekleştirememesi öğretmenlerde hayal kırıklığı, üzüntü ve endişe duygularına yol açmaktadır (Bahia vd., 2013; Chen, 2016; Sutton ve Wheatley, 2003). Mevcut çalışmada yönetici ve öğretmenlerin tespit edilen duygu durumu dikkate alındığında okullardaki öğretim etkinlikleri ve öğrenme performansının onlarda üzüntü ve endişe yaratıcı biçimde olmadığı çıkarımı yapılabilir. Hong Kong ve Çin'de ilköğretim kademesindeki öğretmenlerin olumlu duygular (coşku ve sevgi) yaşamasının temel kaynağını öğrencilerle ve meslektaşlarıyla ilişkileri oluştururken; onların negatif duygularının kaynağında eğitim politika ve uygulamalarındaki değişiklikler ile öğretmenlerin hayatındaki dengesizlikler yer almaktadır (Chen, 2016). Öğretmenlerin duygu durumunu etkileyebilecek faktörler arasında onların mesleki değerlerine yönelik eğitim otoritelerinden gelen yıpratıcı eleştiriler de yer alabilir (Büyükgöze ve Özdemir, 2017; Saunders, 2013). Otorite konumundakilerin eylem ve tutumları, çalışanların eylem ve tutumlarını etkilediğinden özellikle okul yöneticilerinin duygu durumlarının öğretmenlerin duygularını etkilemesi beklenir (Yamamoto vd., 2014). Eğitim politikalarındaki değişiklikler öğretmenleri daha fazla hesapvermek durumunda bırakmakta bu durum ise öğretmenlerde endişe duygusuna sebep olmaktadır. Öğretmenlerin bazı olumsuzluklardan sorumlu tutulması, öğretim dış1 mesleki işyükünün artması ve öğretim uygulamalarında değişiklik yapmaları için zorlanmaları onların korku, endişe ve kızgınlık yaşamasına neden olmaktadır. Bu tür olumsuz duyguları ise eğitim yöneticilerine atfetmektedirler (Saunders, 2003). Öğretmenler, mesleki statülerinin düşmesinden ve anne-babaların baskısından dolayı da üzüntü ve kaygı hissetmektedirler (Chen, 2016). Mevcut çalışmanın gerçekleştiği dönem dikkate alındığında Türkiye'de eğitimciler üzerinde politik ve toplumsal baskı ve olumsuz söylemlerin varlığına karşın araştırmanın raporlanması aşamasında iyileştirici söylemlerin ve uygulamaların gerçekleştirildiğine tanık olunmuştur. Bununla birlikte öğretmen ve yöneticilerin sürekli özverili davranmasını gerektiren düzenlemeler onlarda olumsuz duyguları besleyebilmektedir (Konan vd., 2016). Öğretmenlerin duyguları, toplumsal güç ilişkilerinden ve kültürel değerlerden etkilenmektedir (Zembylas, 2005). Öğretmenlerin toplumsal ve kültürel etkenlerden dolayı olumsuz duygularını ifade etmeyip onları bastırma eğiliminde oldukları bildirilmektedir (Chen, 2016). Bu durum, birikime yol açarak ani ve şiddetli duygusal tepkilere yol açabilir.

$\mathrm{Bu}$ çalışmada öğretmen ve okul yöneticilerinin başkalarına yönelen duygularıyla kendi içlerine yönelen duyguları arasında deneyimlenme yoğunluğu bakımından bir denge olduğu saptanmıştır. Öğretmen ve okul yöneticilerinin kendi içlerinde yaşadıkları duygular arasında en sıklıkla sabır, gurur, neşe, cesaret ve inanma duyguları saptanırken başkalarına yönelen duygulardan en sıklıkla sevgi, ilgi, güven, empati ve merhamet duyguları yaşanmaktadır. Her iki duygu türü de orta düzeyde yaşanmaktadır. Her iki boyutu temsilen en sık yaşanan duygular sabır ve sevgi duygularıdır. Okullarda eğitimcilerin en sık etkileşim halinde olduğu gruplar- öğrenciler ve meslektaşları- dikkate alındığında bu iki duygunun kritik işlevleri belirmektedir. Bireysel farklılıklara odaklanma eğilimi, çeşitlilikle başedebilmede eğitimcilerin sabırlı olmasını gerektirmektedir. Zorluklara rağmen eğitimcilerin işlerini sevdikleri saptanmaktadır (TEDMEM, 2014).

Duyguların, mesleki uygulamalara ve mesleki gelişime etkisi bildirilmektedir (Bahia vd., 2013; Sutton ve Wheatley, 2003). Öğretmenlerin olumlu duygular hissetmesi onların istekliliğini artırabilmekte ve yeni girişimler için güç sağlamaktadır. Olumlu duygular yaşayabilmeleri, yönetimsel yaklaşım ve uygulamalarla ilgilidir çünkü okuldaki her türlü düzenleme ve işleyişten öncelikle okul yönetimi sorumludur (Cemaloğlu ve Gülcan, 2018). Öğretmenlerin olumlu duygularının kaynağında öğrenciler, meslektaşlar ve anne-babalarla ilişkiler yer almaktadır (Chen, 2009). Okul yönetimleri bu kapsamda öğretmenlerin mesleki başarısını dikkate alarak onları destekleyici yaklaşım ve uygulamaları gerçekleştirdiklerinde öğretmenlerin olumlu duygular yaşamasına yardım etmiş olacaklardır (CenksevenÖnder ve Sarı, 2009). Buna ek olarak öğretmenlerin kariyer yapma yolunun işlevsel ve aktif hale getirilmesi, öğretmenlerin duygusal iyiliğini destekleyecektir (Fiorilli, Albanese, Gabola ve Pepe, 2017).

Öğretmenlerin yaşadıkları duyguların onların öğretim uygulamalarına yansıması ve öğrencilerin duygusal gelişimleri üzerindeki etkisi dikkate alınarak öğretmenlerin duygu yönetimi konusunda beceri geliştirmeleri ihtiyacını göstermektedir. Öğretmen yetiştirme sürecinde ve halen öğretmenlik yapmakta olanlara yönelik duygu yönetimi becerisini geliştirici eğitimler verilmesi gerekmektedir (Bahia vd., 2013; Chen, 2016). Duygu yönetimi, özellikle sınıfında kaynaştırma öğrencisi olan öğretmenler için daha çok gerekmektedir çünkü onlar duygusal yıpranmaya daha çok açıktırlar (Fiorilli vd., 2017).

$\mathrm{Bu}$ çalışmada, katılımcıların kişisel beyanlarına dayalı olarak duygu durumları saptanmaya çalışılmıştır. Hissedilen duygu ile bu duygunun ifade edilmesi arasında farklılıklar olabileceği dikkate alınarak bu çalışmada elde edilen sonuçlar açısından duyguların tespitinde izlenen yöntem bir sınırlılık 
oluşturabilir. Sonraki çalışmalar için kişisel beyanların yanı sıra gözlem yapma veya aynı kişilerin belirli zaman aralıklarında kişisel beyanlarındaki tutarlılığa bakılarak duygu durumlarının saptanması yöntemi önerilmektedir. Frenzel vd. (2017) tarafından yapılan çalışmada veri toplama zamanının katılımcıların duygu ifadelerinde farklılığa yol açtığı saptanmıştır. Ayrıca reform dönemlerinde öğretmenlerin duygusal bakımdan daha hassas olacağı kabul edilmektedir (Chen, 2016). Bu çalışma Mart-Haziran döneminde gerçekleştirildiğinden başka bir zaman diliminde gerçekleştirilmesi halinde duygu ifadeleri farklı olabilir. Sınırlılıklarına karşın Türkiye bağlamında öğretmenlerin duygularını betimlemeye odaklı bu ilk çalışmanın alandaki araştırma boşluğunu gidermeye katkı sağlayacağı değerlendirilmektedir. Bu çalışmanın bir başka olumlu yanı duygular üzerinde etkisi olabilecek öğretim kademeleri, farklı branşlar, farklı deneyim gibi farklı değişkenlerin örneklem tarafından kapsanmış olmasıdır. Mevcut çalışmanın benzeri çalışmalardan en önemli farkı duygu çeşitliliği bakımından kapsamının geniş olması yani belirli sayıdaki duygularla sınırlı kalmaması ve duyguları spesifik bir durumla sınırlandırmamasıdır. Çünkü öğretmenler yalnızca bir duruma bağlantılı olarak birden çok duyguyu yaşayabilmektedir. Dolayısıyla bu yaklaşım, ölçme aracının geçerliğini ve araştırmanın geçerliğini artırıcı yönde işlev görmektedir. 


\section{KAYNAKLAR}

Akçay, C. ve Çoruk, A. (2012). Çalışma yaşamında duygular ve yönetimi: Kavramsal bir inceleme. Ĕ̌gitimde politika analizi dergisi. 1(1), 3-25.

Akdoğan, E. (2016). Karar verme süreci açısından okul yöneticilerinin duygusal işyüklerini yönetme durumlarının incelenmesi. Yayınlanmamış Yüksek Lisans Tezi, Aksaray Üniversitesi Sosyal Bilimler Enstitüsü, Aksaray.

Andrew, K., Richards, R., Hemphill, M.A. \& Templin, T.J. (2018). Personal and contextual factors related to teachers' experience with stress and burnout, Teachers and Teaching, 24(7), 768-787. DOI: $10.1080 / 13540602.2018 .1476337$

Ayçiçek, G. (2012). Olumlu ve olumsuz duyguların işgören motivasyonu üzerindeki etkileri ve bir uygulama (Yayınlanmamış yüksek lisans tezi). İnönü Üniversitesi Sosyal Bilimler Enstitüsü, Malatya.

Bahia, S., Freire, I., Amaral, A., \& Estrela, M. A. (2013). The emotional dimension of teaching in a group of Portuguese teachers. Teachers and Teaching: Theory and Practice, 19(3), $275 \mathrm{e} 292$. http://dx.doi.org/10.1080/13540602.2012.754160.

Bakioğlu, A. (2014). Çăgdaş sınıf yönetimi. Ankara: Nobel.

Barutçugil, İ. (2002). Organizasyonlarda duyguların yönetimi.1. Baskı. İstanbul: Kariyer Yayıncılık.

Becker, E.S., Goetz, T., Morger, V. and Ranellucci, J. (2014). The importance of teachers' emotions and instructional behaviour for their students' emotions: An experience sampling analysis. Teaching and Teacher Education, 43, $15-26$.

Bricheno, P., Brown, S., \& Lubansky, R. (2009). Teacher well-being: a review of evidence. Teacher Support Network. Available from http://www.scribd.com/doc/.

Burić, I., Slišković, A. \& Macuka, I. (2018). A mixed-method approach to the assessment of teachers' emotions: development and validation of the Teacher Emotion Questionnaire, Educational Psychology, 38(3), 325-349. DOI: 10.1080/01443410.2017.1382682.

Bursalığlu, Z. (2002). Okul yönetiminde yeni yapı ve davranış. Ankara: PegemA.

Büyükgöze, H. ve Özdemir, M. (2017). İş doyumu ile öğretmen performansı ilişkisinin Duygusal Olaylar Kuramı çerçevesinde incelenmesi. Inönü Üniversitesi Eğitim Fakültesi Dergisi, 18(1), 311-325. DOI: 10.17679/inuefd.307041

Büyüköztürk, Ş., Çakmak, E., Akgün, Ö., Karadeniz, Ş. ve Demirel, F. (2014). Bilimsel Araştırma Yöntemleri. Ankara: Pegem A

Cangelosi, J.S. (2014). Classroom management strategies. 7. Edition. Danvers: Wiley.

Cemaloğlu, N. ve Gülcan, M.G. (Ed.). (2018). Kuramdan uygulamaya okul yönetimi [School administration through theories and practices]. Ankara: PegemA.

Cenkseven-Önder, F. ve Sar1, M. (2009). The quality of school life and burnout as predictors of subjective wellbeing among teachers. Educational Science: Theory \& Practice, 9, 1223-1236.

Chen, J. (2016). Understanding teacher emotions: The development of teacher emotion inventory. Teaching and Teacher Education, 55, 68-77.

Chernyshenko, O., Kankaraš, M. and Drasgow, F. (2018). Social and emotional skills for student success and wellbeing: Conceptual framework for the OECD study. Paris: OECD Publication

Cross, D. I., \& Hong, J. Y. (2012). An ecological examination of teachers' emotions in the school context. Teaching and Teacher Education, 28, 957-967. http://dx.doi.org/10.1016/j.tate.2012.05.001.

Çalık, T. (2003). Eğitimde değişimin yönetimi: Kavramsal bir çözümleme. Kuram ve Uygulamada Egitim Yönetimi Dergisi, 9(4), 536-557.

Çokluk, Ö., Şekercioğlu, G. ve Büyüköztürk, Ş. (2010). Çok değişkenli istatistik: SPSS ve LISREL uygulamaları [Statistics for multiple variables: Practices in SPSS and LISREL]. Ankara: PegemA.

Day, C. \& Leitch, R. (2001). Teachers' and teacher educators' lives: The role of emotion. Teaching and Teacher Education, 17, 403-415.

Demirtaş, Z. ve Küçük, Ö. (2016). Öğretmenlerin örgütsel sinizm algıları. İçinde Beycioğlu, K., Özer, N., Koşar, D., Şahin, İ. (Edt) Eğitim araştırmaları e-kitap (180-192). Ankara: PegemA.

Edmondson, A. C., Kramer, R. M. \& Cook, K.S. (2004). Psychological safety, trust, and learning in organizations: A group-level lens. Trust and distrust in organizations: Dilemmas and approaches 12, 239-272.

Eren, E. (2001). Örgütsel davranış ve yönetim psikolojisi. İstanbul: Beta Yayınları.

Farouk, S. (2012). What can the self-conscious emotion of guilt tell us about primary school teachers' moral purpose and the relationships they have with their pupils? Teachers and Teaching: Theory and Practice, 18(4), $491 \mathrm{e} 507$.

Fiorilli, C., Albanese, O., Gabola, P. \& Pepe, A. (2017). Teachers' Emotional Competence and Social Support: Assessing the Mediating Role of Teacher Burnout. Scandinavian Journal of Educational Research, 61 (2), 127 138, DOI:10.1080/00313831.2015.1119722

Fraenkel, J.R., Wallen, N.E. \& Hyun, H.H. (2012). How to design and evaluate research in education. NY: McGrawHill.

Frenzel, A., Becker-Kurz, B., Pekrun, R., Goetz, T., \& Lüdtke, O. (2017). Emotion transmission in classroom revisited: A reciprocal effects modal of teacher and student enjoyment. Journal of Educational Psychology, $110(5), 628-639$.

Gasser, L., Grütter, J., Buholzer, A. \& Wettstein, A. (2018). Emotionally supportive classroom interactions and students' perceptions of their teachers as caring and just. Learning and Instruction, 54, 82-92. 
Harter, J.K. ve Arora, R. (2010). The impact of time spent working and job fit on well-being around the World. İçinde E. Diener, J.F. Helliwell \& D. Kahneman (Eds). International differences in well-being (398-435). New York: Oxford.

Jennings, P. A., \& Greenberg, M. T. (2009). The prosocial classroom: Teacher social and emotional competence in relation to student and classroom outcomes. Review of educational research, 79(1), 491-525.

Jöreskog, K., \& Sörbom, D. (1996). LISREL 8: User's Reference Guide. Chicago: Scientific Software International.

Kervanc1, F. (2008). Büro çalışanlarının duygu yönetimi yeterlilik düzeylerinin geliştirilmesinde duygu yönetimi eğitimi programının etkisi (Yayınlanmamış yüksek lisans tezi). Gazi Üniversitesi, Eğitim Bilimleri Enstitüsü, Ankara.

Kline, R.B. 2011. Principles and practice of structural equation modelling. New York: The Guilford Pub.

Konan, N., Çetin, R.B. ve Bozanoğlu, B. (2016). Okul müdürlerinin tükenmişlik düzeyleri. İçinde Beycioğlu, K., Özer, N., Koşar, D., Şahin, İ. (Edt) Eğitim araştırmaları e-kitap (327-339). Ankara: PegemA.

Leithwood, K. \& Beatty, B. (2008). Leading with Teacher Emotions in Mind. Thousand Oaks, CA: Corwin.

Li, Y. ve Ahlstrom, D. (2016). Emotional stability: A new construct and its implications for individual behavior in organizations. Asia Pacific Journal of Management, 33, 1-28. Doi: 10.1007/s10490-015-9423-2.

Lunenburg, F.C. \& Ornstein, A.C. (2013). Educational Administration [Ĕ̈itim Yönetimi]. (Tran. Ed. G. Arastaman). Ankara: Nobel Yayıncılık. (Original edition 6. Publication year, 2012).

Miller, P. (2012). Ten characteristics of a good teacher. English Teaching Forum, 50(1), 36-38.

Morgan, C.T. (2010). Psikolojiye giriş (S. Karakaş ve R. Eski, Çev.). Konya: Eğitim Akademi

Murphy, N. ve Hall, J. (2011). Intelligence and interpersonal sensitivity: A meta-analysis. Intelligence, 39 (1), 54-63. http://dx.doi.org/10.1016/j.intell.2010.10.001.

Nias, J. (1996). Thinking about feeling: The emotions in teaching. Cambridge journal of education, 26(3), 293-306.

Oplatka, I. ve Arar, K. (2018). Increasing teacher and leader professionalism through emotion management and engagement. Journal of Professional Capital and Community, 3 (3), 138-141, https://doi.org/10.1108/JPCC-072018-036

Özdemir, M. ve Koçak, S. (2018). Predicting teacher emotional labour based on multi-frame leadership orientations: A case from Turkey. Irish Educational Studies, 37 (1), 69-87.

Parrott, W. (2001). Emotions in social psychology. Philadelphia: Psychology Press.

Pekrun, R. (2000). A social-cognitive, control-value theory of achievement emotions. In J. Heckhausen (Ed.), Motivational psychology of human development (143-163). Oxford, UK: Elsevier. http://dx.doi.org/10.1016/S0166-4115(00)80010-2

Robbins, S. P. ve Judge, T. A. (2015). Organizational behavior. New Jersey: Pearson.

Saunders, R. (2013). The role of teacher emotions in change: Experiences, patterns and implications for professional development. Journal of Educational Change 14, 303-333. http://dx.doi.org/10.1007/s10833-012-9195-0.

Schenke, K., Ruzek, E., Lam, A.C., Karabenick, S.A. \& Eccles, J.S. (2018). To the means and beyond: understanding variation in students' perceptions of teacher emotional support. Learning and Instruction, 55, 13-21.

Scherer, K. R. (2005). What are emotions? And how can they be measured? Social Science Information, 44, 695-729. http://dx.doi.org/10.1177/0539018405058216.

Scherer, K. R. (2009). The dynamic architecture of emotion: Evidence for the component process model. Cognition \& Emotion, 23, 1307-1351. doi:10.1080/02699930902928969

Sezer, Ş. (2016). Öğretmenlerin sınıf yönetiminde sergilediği tutumların öğrencilerin gelişimi üzerindeki etkileri: Fenomenolojik bir çözümleme. İçinde Beycioğlu, K., Özer, N., Koşar, D., Şahin, İ. (Edt) Eğitim araştırmaları e-kitap (553-566). Ankara: PegemA.

Sutton, R.E. \& Wheatley, K.F. (2003). Teachers' emotions and teaching: a review of the literature and directions for future research. Educational Psychology Review, 15 (4), 327-358.

Şişman, M. (2014). Eğitim bilimine giriş. Ankara: PegemA.

Tarhan, N. (2006). Duyguların dili: duygusal zekâya yeni bir yorum. İstanbul: Timaş Yayınları

TEDMEM (Türk Eğitim Derneği). (2014). Öğretmen gözüyle öğretmenlik mesleği. Ankara: TED Yayınları. www.tedmem.org/yayin adresinden erişilmiştir.

Töremen, F. ve Çankaya, İ. (2008). Yönetimde etkili bir yaklaşım: Duygu yönetimi. Kuramsal Eğitimbilim, 1 (1), 33 47.

Weiss, H. M. (2002). Deconstructing job satisfaction: Separating evaluations, beliefs and affective experiences. Human Resource Management Review, 12, 173-194.

Yamamoto, J.K., Gardiner, M.E. \& Tenuto, P.L. (2014). Emotion in leadership: Secondary schooladministrators' perceptions of critical incidents. Educational Management, Administration \& Leadership, 42(2), 165-183.

Yaylacı, G.Ö. (2006). Kariyer yaşamında duygusal zekâ ve iletişim yeteneği "diyalog ve duyguları yönetmek. İstanbul: Hayat Yayıncilık.

Yıldırım, K.\& Yenipinar, Ş. (2017). Psychological unsafety in schools: The development and validation of a scale. Journal of Education and Training Studies, 5(6), 167-176. doi:10.11114/jets.v5i6.2372.

Zembylas, M. (2005). Discursive practices, genealogies, and emotional rules: A poststructuralist view on emotion and identity in teaching. Teaching and Teacher Education, 21(8), 935-948. 